2016 Annual Reuse Report for the Idaho National Laboratory Site's Advanced Test Reactor Complex Cold Waste Ponds

February 2017

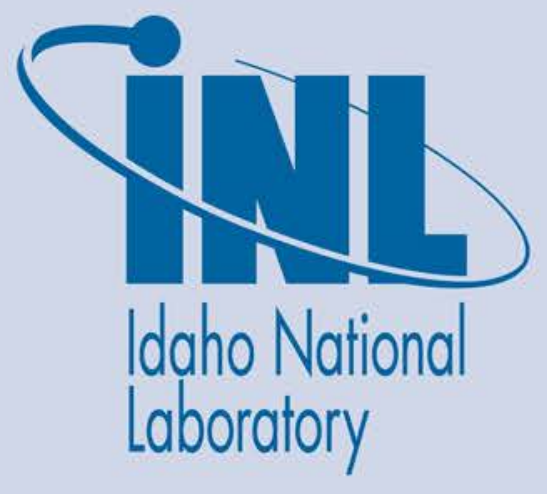

The INL is a U.S. Department of Energy National Laboratory operated by Battelle Energy Alliance 


\section{Annual Reuse Report for the Idaho National Laboratory Site's Advanced Test Reactor Complex Cold Waste Ponds}

February 2017

Idaho National Laboratory Idaho Falls, Idaho 83415

http://www.inl.gov

Prepared for the

U.S. Department of Energy

Office of Nuclear Energy, Science, and Technology

Under DOE Idaho Operations Office

Contract DE-AC07-05ID14517 



\begin{abstract}
This report describes conditions and information, as required by the state of Idaho, Department of Environmental Quality Reuse Permit I-161-02, for the Advanced Test Reactor Complex Cold Waste Ponds located at Idaho National Laboratory from November 1, 2015-October 31, 2016. The effective date of Reuse Permit I-161-02 is November 20, 2014 with an expiration date of November 19, 2019. This report contains the following information:
\end{abstract}

- Facility and system description

- $\quad$ Permit required effluent monitoring data and loading rates

- $\quad$ Permit required groundwater monitoring data

- Status of compliance activities

- Issues

- Discussion of the facility's environmental impacts.

During the 2016 permit year, 180.99 million gallons of wastewater were discharged to the Cold Waste Ponds. This is well below the maximum annual permit limit of 375 million gallons.

As shown by the groundwater sampling data, sulfate and total dissolved solids concentrations are highest in well USGS-065, which is the closest downgradient well to the Cold Waste Ponds. Sulfate and total dissolved solids concentrations decrease rapidly as the distance downgradient from the Cold Waste Ponds increases. Although concentrations of sulfate and total dissolved solids are significantly higher in well USGS-065 than in the other monitoring wells, both parameters remained below the Ground Water Quality Rule Secondary Constituent Standards in well USGS-065.

The facility was in compliance with the Reuse Permit during the 2016 permit year. 


\section{CONTENTS}



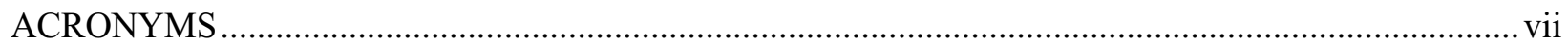

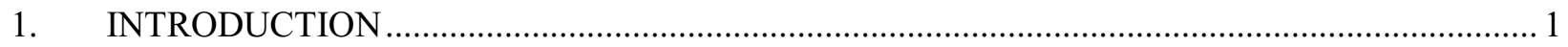

2. FACILITY, SYSTEM DESCRIPTION, AND OPERATION ….................................................... 1

3. COLD WASTE PONDS EFFLUENT MONITORING ........................................................... 4

3.1 Sampling Program and Analytical Methods ....................................................................... 4

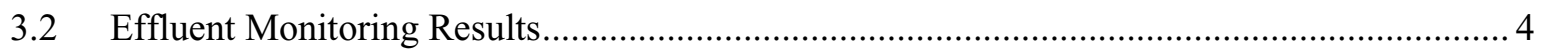

3.3 Flow Volumes and Hydraulic Loading Rates ............................................................... 8

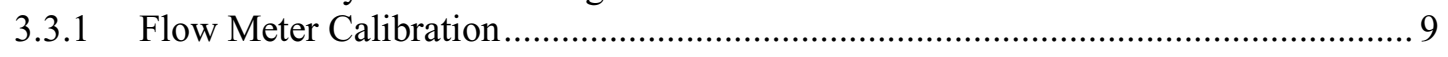



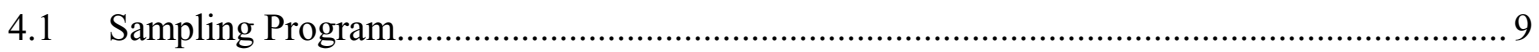

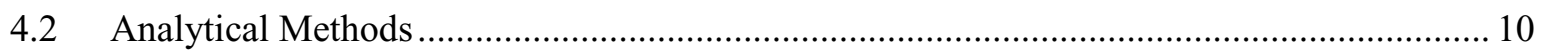

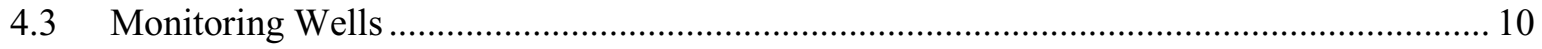

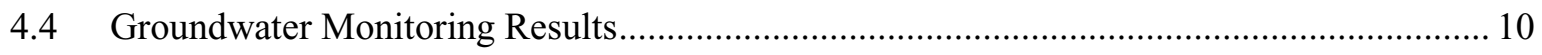

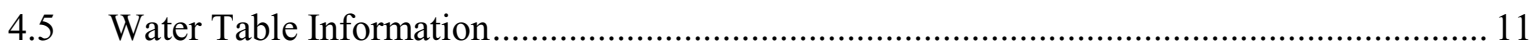

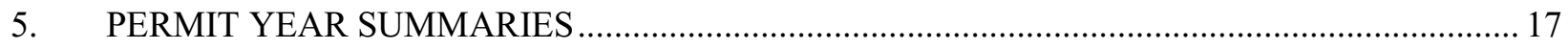

5.1 Status of Permit Required Compliance Activities............................................................. 17

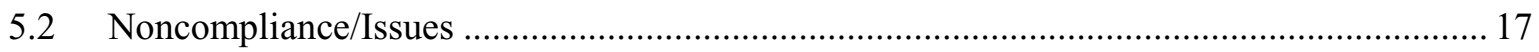

5.3 Department of Environmental Quality Annual Inspection .............................................. 18

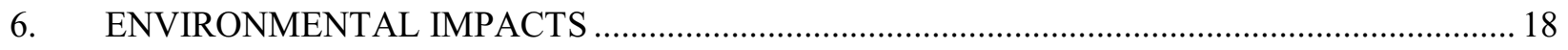

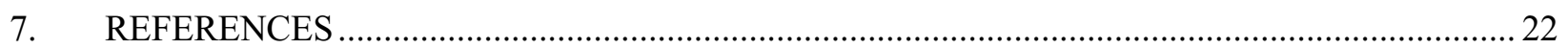

Appendix A Daily Discharge Volumes to the Advanced Test Reactor Complex Cold Waste Ponds

\section{FIGURES}

Figure 1. Advanced Test Reactor Complex facility map showing location of the Cold Waste Ponds, monitoring and drinking water wells, Big Lost River, and other associated surface features.

Figure 2. Advanced Test Reactor Complex Cold Waste system flow schematic...................................... 3

Figure 3. Advanced Test Reactor Complex Cold Waste Ponds wastewater 5-year moving average........... 9

Figure 4. Map showing depths and elevations based on the May 2016 water level measurements. .......... 15

Figure 5. Map showing depths and elevations based on the September 2016 water level measurements. 
Figure 6. Sulfate concentrations in the Cold Waste Ponds monitoring wells.

Figure 7. Total dissolved solids concentrations in the Cold Waste Ponds monitoring wells.

\section{TABLES}

Table 1. Advanced Test Reactor Complex Cold Waste Ponds effluent (WW-16101) data for samples collected in accordance with Reuse Permit I-161-02.

Table 2. Cold Waste Ponds flow summaries.

Table 3. Advanced Test Reactor Complex Cold Waste Ponds aquifer monitoring well data for the 2016 reporting year.

Table 4. Mann-Kendall trend analysis results for sulfate in the groundwater monitoring wells. 20

Table 5. Mann-Kendall trend analysis results for total dissolved solids in the groundwater monitoring wells. .21

Table A-1. Daily discharge volumes to the ATR Complex CWPs for the 2016 permit year. .25 


\section{ACRONYMS}

ATR Advanced Test Reactor

CCN correspondence control number

CFR Code of Federal Regulations

CTS Commitment Tracking System

CWPs Cold Waste Pond(s)

DEQ Idaho Department of Environmental Quality

EPA U.S. Environmental Protection Agency

FM flow measurement or monitoring description or identifier

GW prefix for groundwater reporting serial number

IDAPA Idaho Administrative Procedures Act

INL Idaho National Laboratory

MDL method detection limit

MG million gallons

MS matrix spike

MU prefix for management unit reporting environmental serial number

NA Not Applicable

NAVD North American Vertical Datum

OOS out of service

PCS Primary Constituent Standard

PO Plan of Operation

QAPP Quality Assurance Project Plan

RL reporting limit

R\&MS Regulatory and Monitoring Services

RPD relative percent difference

SCS Secondary Constituent Standard

s.u. $\quad$ standard units for $\mathrm{pH}$

TDS total dissolved solids

TKN total Kjeldahl nitrogen

TN total nitrogen

TRA prefix for groundwater reporting (well) common designation number

USGS prefix for groundwater reporting (well) common designation number

WW prefix for wastewater reporting serial number 


\section{Annual Reuse Report for the Idaho National Laboratory Site's Advanced Test Reactor Complex Cold Waste Ponds \\ 1. INTRODUCTION}

The Advanced Test Reactor (ATR) Complex Cold Waste Ponds (CWPs) is a reuse facility operated by Battelle Energy Alliance, LLC at Idaho National Laboratory (INL) under Reuse Permit No. I-161-02 issued by the State of Idaho Department of Environmental Quality (DEQ) on November 20, 2014 (Neher 2014) and expires on November 19, 2019.

This annual report summarizes the facility system and operation, monitoring data, special compliance conditions, issues/noncompliances, and environmental impacts for the 2016 reporting year (November 1, 2015, through October 31, 2016).

\section{FACILITY, SYSTEM DESCRIPTION, AND OPERATION}

The ATR Complex (Figure 1) is located on approximately 100 acres in the southwestern portion of INL, approximately 47 miles west of Idaho Falls, Idaho, in Butte County. The ATR Complex consists of buildings and structures utilized to conduct research associated with developing, testing, and analyzing materials used in nuclear and reactor applications and both radiological and nonradiological laboratory analyses.

The CWPs are located approximately $450 \mathrm{ft}$ from the southeast corner of the ATR Complex compound and approximately $3 / 4$ of a mile northwest of the Big Lost River channel (Figure 1). The existing CWPs were excavated in 1982. The CWPs consist of two cells, each with dimensions of $180 \times$ $430 \mathrm{ft}$ across the top of the berms, and a depth of $10 \mathrm{ft}$. Total surface area for the two cells at the top of the berms is approximately 3.55 acres. Maximum capacity is approximately 10,220,000 gal (31.3 acre $\mathrm{ft}$ ).

Wastewater discharged to the CWPs consists primarily of noncontact cooling tower blowdown, once-through cooling water for air conditioning units, coolant water from air compressors, secondary system drains, and other nonradioactive drains throughout the ATR Complex. The wastewater flows through collection piping to the TRA-764 Cold Waste Sample Pit (Figure 2) where the flow rate is recorded and compliance monitoring samples are collected. The wastewater then flows to the Cold Waste Sump Pit (TRA-703). The sump pit contains submersible pumps that route the water to the appropriate pond through 8 -in. valves.

Wastewater enters the ponds through concrete inlet basins located near the west end. Most of the water percolates into the porous ground within a short distance from the inlet basins. The entire floor of a pond is rarely submerged. If the water level rises significantly in a pond (e.g., $5 \mathrm{ft}$ ), the flow would be diverted to the adjacent pond, allowing the first pond to dry out. An overflow pipe connects the two ponds at the 9-ft level.

Normal operation is to route the wastewater to one pond at a time. Historically, the flow to the ponds was switched annually. Section 4.2 of the Reuse Permit states "DEQ recommends each basin be operated using periods of wetting and drying cycles at set frequencies that provide for both anaerobic and aerobic treatment of the wastewater through the vadose zone."

Beginning in February 2015, the frequency for switching ponds was increased to approximately monthly. The dates when the effluent flow to the ponds were switched can be found in Appendix A. The change in frequency is based on a modeled vadose zone drain-out period for the zone above the shallow perched water zone below the CWPs. 
There are no existing or planned cross-connections or interconnections between the Cold Waste System wastewater and any water supplies (potable or nonpotable) that would require backflow prevention devices or methods.

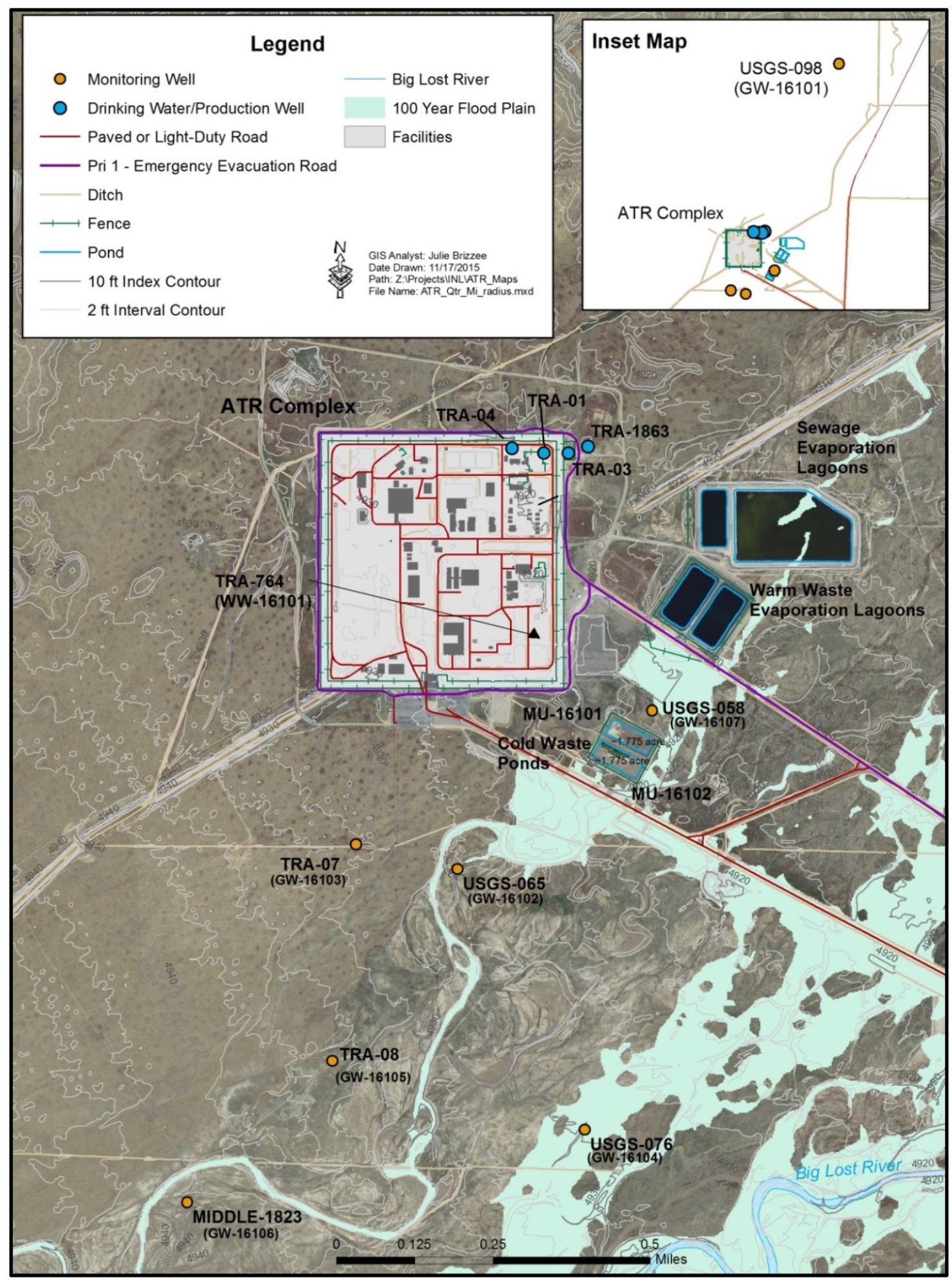

Figure 1. Advanced Test Reactor Complex facility map showing location of the Cold Waste Ponds, monitoring and drinking water wells, Big Lost River, and other associated surface features. 


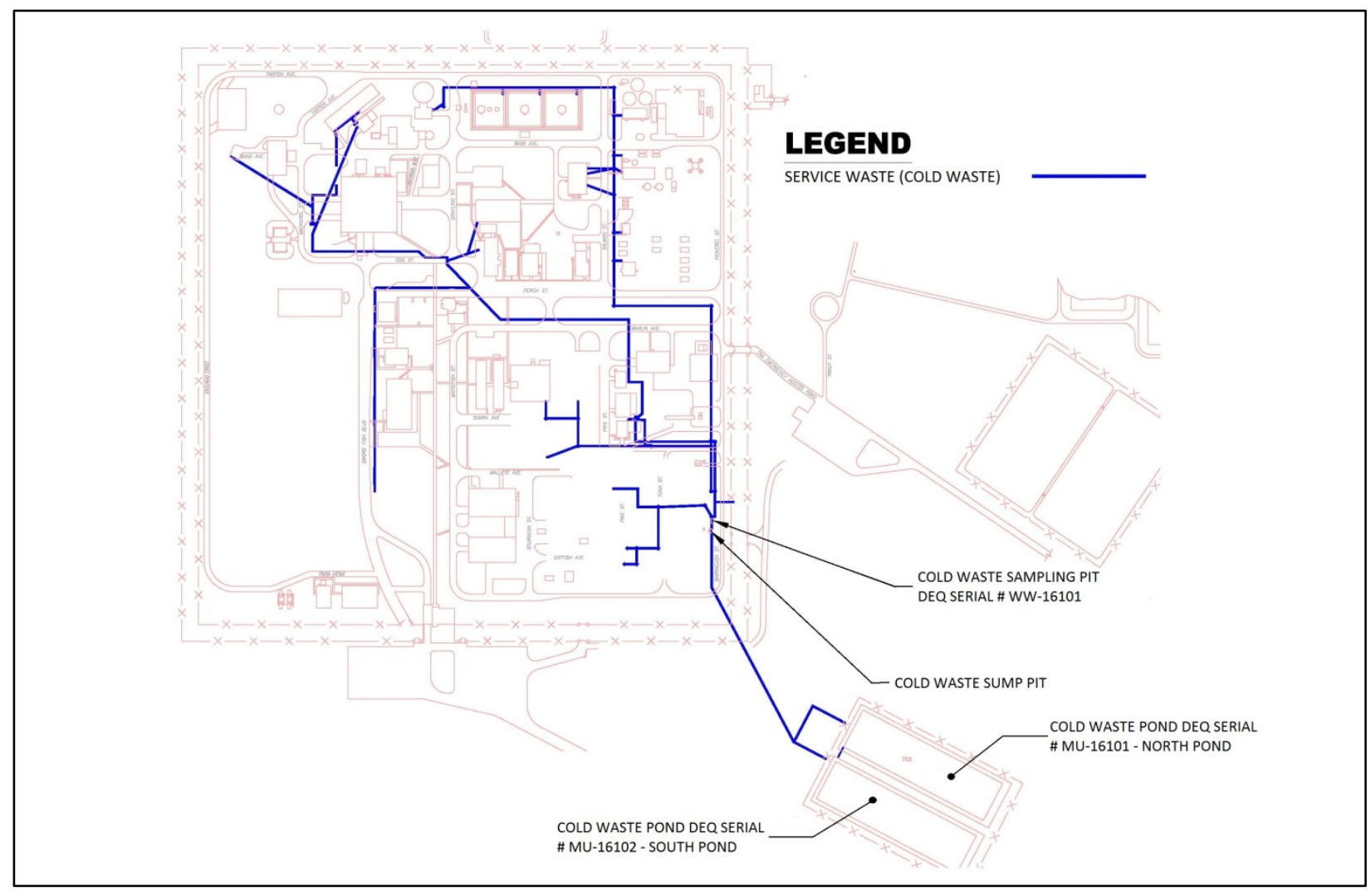

Figure 2. Advanced Test Reactor Complex Cold Waste system flow schematic. 


\section{COLD WASTE PONDS EFFLUENT MONITORING}

This section describes the sampling and analytical methods used in the ATR Complex CWPs effluent monitoring program. Effluent monitoring and flow data for wastewater discharged to the ATR Complex CWPs are provided.

\subsection{Sampling Program and Analytical Methods}

Battelle Energy Alliance, LLC, Regulatory and Monitoring Services (R\&MS) personnel monitor effluent discharges at the ATR Complex CWPs. The R\&MS program involves sampling, analysis, and data interpretation carried out under a quality assurance program. A Quality Assurance Project Plan (QAPP), as required by the Reuse Permit, was submitted to DEQ on May 18, 2015 (Miller 2015a).

The QAPP identifies the scope of monitoring, the organization and individuals involved, data quality objectives, monitoring procedures, and specific quality control measures. The purpose of the QAPP is to ensure data of sufficient quantity and quality are collected to meet permit and regulatory expectations.

Regulatory and Monitoring Services personnel collect monthly effluent samples as required in Section 5.1.1 of the Reuse Permit. Effluent samples were collected from the TRA-764 Cold Waste Sample Pit (sampling location WW-16101) prior to discharge to the CWPs. All samples were collected according to established programmatic sampling procedures. These procedures are now identified in the QAPP.

Effluent sampling events are randomly scheduled within the constraints of the sampling staff and laboratory availability. Effluent samples are typically collected early in the month (first or second week) and on a Tuesday or Wednesday of the selected week. This ensures the laboratory can receive the samples during normal working hours so that temperature control and holding time requirements are met. This also allows time in the month to collect samples in the event there are issues with the original samples, sampling equipment, flow meter, etc. The WW-16101 January sampling event, originally scheduled for January 13, 2016, was rescheduled to January 21, 2016, due to unavailability of sampling staff.

Analytical methods specified in 40 Code of Federal Regulations (CFR) 141, "National Primary Drinking Water Regulations"; 40 CFR 143, "National Secondary Drinking Water Regulations," or 40 CFR 136, "Guidelines Establishing Test Procedures for the Analysis of Pollutants" were used for analysis of all permit-required parameters.

Permit required effluent $\mathrm{pH}$ and conductivity analyses are performed at the time of sample collection by R\&MS personnel using a calibrated meter. All other permit required samples were submitted under full chain of custody to GEL Laboratories in Charleston, South Carolina for analyses beginning January 2016. Prior samples were submitted to Southwest Research Institute's Analytical and Environmental Chemistry Department located in San Antonio, Texas.

\subsection{Effluent Monitoring Results}

The permit year covered in this report is November 1, 2015-October 31, 2016.

Effluent samples were collected monthly from the TRA-764 Cold Waste Sample Pit (prior to discharge to the CWPs) during the permit year. Effluent samples were collected as 24-hour flow proportional composite samples. All samples were collected and analyzed as required by the permit (Table 1).

Total nitrogen is a permit required parameter. Total nitrogen is calculated as the sum of total Kjeldahl nitrogen (TKN) and nitrate plus nitrite nitrogen. There are no permit limits for total nitrogen.

Although, there are no effluent permit limits for total dissolved solids (TDS) or sulfate, these parameters are found at elevated levels in groundwater monitoring well USGS-065. A summary 
comparison of these parameters with the Ground Water Quality Rule Secondary Constituent Standards (SCS) found in Idaho Administrative Procedures Act (IDAPA) 58.01.11.200.01.b. is provided below:

The TDS SCS is $500 \mathrm{mg} / \mathrm{L}$. The TDS concentration in the effluent to the CWPs ranged from 189 $\mathrm{mg} / \mathrm{L}$ in the April 2016 sample to 1,300 mg/L in the March 2016 sample (Table 1). Concentrations of TDS in the effluent were above the SCS level in 3 out of the 12 months.

Similar to the TDS effluent levels, sulfate concentrations were above the SCS of $250 \mathrm{mg} / \mathrm{L}$ in 3 of the 12 monthly samples (Table 1). Sulfate ranged from a minimum of $20.1 \mathrm{mg} / \mathrm{L}$ in the April 2016 sample to a maximum of $628 \mathrm{mg} / \mathrm{L}$ in the March 2016 sample.

The ATR evaporative cooling process evaporates approximately one-half of the water volume and concentrates naturally occurring TDS and additives in the blowdown discharged to the CWPs. Elevated sulfate levels are generated by reactions between sulfuric acid additives placed in the cooling water and calcium and magnesium carbonates in the water.

The metals concentrations in the CWPs effluent remained at low levels (Table 1). 
Table 1. Advanced Test Reactor Complex Cold Waste Ponds effluent (WW-16101) data for samples collected in accordance with Reuse Permit I161-02.

\begin{tabular}{|c|c|c|c|c|c|c|c|c|c|c|c|c|}
\hline Sample Month & November & December & January & February & March & April & May & June & July $^{\mathrm{a}}$ & August & September & October \\
\hline Sample Date & $11 / 10 / 15$ & $12 / 08 / 15$ & $01 / 21 / 16$ & $02 / 09 / 16$ & $03 / 08 / 16$ & $04 / 12 / 16$ & $05 / 10 / 16$ & $06 / 21 / 16$ & $07 / 12 / 16$ & $08 / 17 / 16$ & $09 / 07 / 16$ & $10 / 18 / 16$ \\
\hline $\begin{array}{c}\text { Nitrite + nitrate as nitrogen } \\
(\mathrm{mg} / \mathrm{L})\end{array}$ & 0.875 & 2.92 & 0.877 & $0.879 \mathrm{~J}^{\mathrm{b}}$ & 3.91 & $0.981 \mathrm{~J}$ & 0.929 & 1.08 & $\begin{array}{l}0.895 \\
{[0.91]} \\
\end{array}$ & 0.92 & 0.955 & 3.11 \\
\hline $\begin{array}{c}\text { Total Kjeldahl nitrogen } \\
(\mathrm{mg} / \mathrm{L})\end{array}$ & 0.176 & 1.03 & $0.0942 \mathrm{~J}$ & $-0.0457 \mathrm{U}^{\mathrm{c}}$ & 1.11 & 0.0272 & $-0.00597 \mathrm{U}$ & $0.0367 \mathrm{~J}$ & $\begin{array}{c}-0.0648 \mathrm{U} \\
{[-0.0135 \mathrm{U}]}\end{array}$ & $-0.0169 \mathrm{UJ}^{\mathrm{d}}$ & $-0.0693 \mathrm{U}$ & 0.309 \\
\hline Total nitrogen $^{\mathrm{e}}(\mathrm{mg} / \mathrm{L})$ & 1.051 & 3.95 & 0.971 & 0.879 & 5.02 & 1.0082 & 0.929 & 1.1167 & $\begin{array}{l}0.895 \\
{[0.91]}\end{array}$ & 0.92 & 0.955 & 3.419 \\
\hline $\mathrm{pH}$ (s.u.) & 8.06 & 7.87 & 7.71 & 7.76 & 7.26 & 7.87 & 7.82 & 7.33 & 7.27 & 7.18 & 7.17 & 7.10 \\
\hline $\begin{array}{c}\text { Electrical conductivity } \\
(\mu \mathrm{S} / \mathrm{cm})\end{array}$ & 463 & 1,320 & 427 & 511 & 1,453 & 399 & 380 & 468 & 389 & 448 & 486 & 1164 \\
\hline Chloride (mg/L) & 15.8 & 39.7 & 9.62 & 13.5 & 42 & $9.84 \mathrm{~J}$ & 9.56 & 12.9 & $\begin{array}{r}9.65 \\
{[9.67]} \\
\end{array}$ & 9.89 & 13.1 & 34.1 \\
\hline Sulfate $(\mathrm{mg} / \mathrm{L})$ & 42.8 & 546 & 23 & 46.4 & 628 & 20.1 & 21.8 & 56.2 & $\begin{array}{c}21.9 \\
{[21.8]}\end{array}$ & 21.9 & 33.2 & 461 \\
\hline Total dissolved solids $(\mathrm{mg} / \mathrm{L})$ & 254 & 1,000 & 310 & 316 & 1,300 & $189 \mathrm{~J}$ & $234 \mathrm{~J}$ & 249 & $\begin{array}{c}200 \\
{[217]}\end{array}$ & 211 & $211 \mathrm{~J}$ & $833 \mathrm{~J}$ \\
\hline Aluminum, filtered (mg/L) & $0.025 \mathrm{U}$ & $0.025 \mathrm{U}$ & $0.015 \mathrm{U}$ & $0.015 \mathrm{U}$ & $0.015 \mathrm{U}$ & $0.015 \mathrm{U}$ & $0.015 \mathrm{U}$ & 0.065 & $\begin{array}{c}0.015 \mathrm{U} \\
{[0.015 \mathrm{U}]}\end{array}$ & 0.0265 & $0.0015 \mathrm{U}$ & $0.015 \mathrm{U}$ \\
\hline Chromium, total (mg/L) & $0.00527 \mathrm{~J}$ & 0.0106 & 0.00446 & 0.00519 & 0.0126 & 0.00346 & 0.00307 & 0.00396 & $\begin{array}{c}0.00404 \\
{[0.00363]}\end{array}$ & 0.00416 & 0.00407 & 0.00969 \\
\hline Chromium, filtered (mg/L) & $0.00519 \mathrm{~J}$ & 0.0105 & 0.00408 & 0.00501 & 0.0134 & 0.00354 & 0.00273 & 0.00294 & $\begin{array}{c}0.00376 \\
{[0.00388]}\end{array}$ & 0.00333 & 0.00412 & 0.00922 \\
\hline Iron, filtered $(\mathrm{mg} / \mathrm{L})$ & $0.025 \mathrm{U}$ & 0.0253 & 0.0488 & $0.033 \mathrm{U}$ & $0.033 \mathrm{U}$ & $0.033 \mathrm{U}$ & 0.100 & 0.103 & $\begin{array}{c}0.033 \mathrm{U} \\
{[0.033 \mathrm{U}]}\end{array}$ & 0.0779 & 0.093 & $0.033 \mathrm{U}$ \\
\hline Manganese, filtered (mg/L) & $0.0025 \mathrm{U}$ & 0.00303 & $0.001 \mathrm{U}$ & $0.001 \mathrm{U}$ & 0.00204 & $0.001 \mathrm{U}$ & $0.001 \mathrm{U}$ & $0.001 \mathrm{U}$ & $\begin{array}{c}0.001 \mathrm{U} \\
{[0.001 \mathrm{U}]}\end{array}$ & $0.001 \mathrm{U}$ & $0.001 \mathrm{U}$ & 0.0019 \\
\hline $\begin{array}{l}\text { a. Results shown in brackets ar } \\
\text { b. J flag indicates the associate } \\
\text { c. U flag indicates that the resu } \\
\text { d. UJ flag indicates the sample } \\
\text { e. Total nitrogen is calculated } \\
\text { considered zero when used in t }\end{array}$ & $\begin{array}{l}\text { from field du } \\
\text { value is an es } \\
\text { was reported } \\
\text { as analyzed } \\
\text { the sum of th } \\
\text { calculation. }\end{array}$ & $\begin{array}{l}\text { cate samples } \\
\text { nate and mas } \\
\text { below the i } \\
\text { but was no } \\
\text { TKN, nitrite }\end{array}$ & $\begin{array}{l}\text { lected in } \mathrm{J} \\
\text { inaccurate } \\
\text { Iment dete } \\
\text { ected. The } \\
\text { ogen, and } \mathrm{n}\end{array}$ & $\begin{array}{l}\text { imprecise. } \\
\text { n limit by th } \\
\text { ociated valu } \\
\text { ate nitrogen. }\end{array}$ & $\begin{array}{l}\text { alytical lab } \\
\text { an estimate } \\
\text { results repo }\end{array}$ & $\begin{array}{l}\text { ry. } \\
\text { may be inac } \\
\text { below the } 1\end{array}$ & $\begin{array}{l}\text { ate or impreci } \\
\text { ratory instrum }\end{array}$ & tectio & 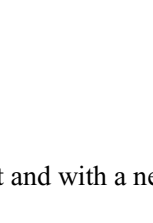 & (s) & mple re & \\
\hline
\end{tabular}


Several effluent sample results were qualified during data validation. Although the reported concentrations may be considered questionable, inaccurate, or imprecise, the estimated values are provided in Table 1. These qualified data are discussed below:

- The November 10, 2015, filtered and unfiltered chromium sample results were qualified with a $\mathrm{J}$ flag by the laboratory. The $\mathrm{J}$ flag indicates the analyte was detected at or above the laboratory's reporting limit but below the requested detection limit.

- The TKN result for the sample collected on January 21, 2016, was qualified with a J flag by the laboratory to designate an estimated result.

- The February 9, 2016, nitrate/nitrite sample result was J flagged during data validation. The nitrate/nitrite sample result was greater than the method detection limit (MDL) and outside the matrix spike (MS) 90\%-110\% recovery criteria per the EPA Method and the Inorganic Analyses Data Validation for INL (GDE-8511), section 4.3.9.5.4 at 89.1\%. The J flag for the February 9, 2016, nitrate/nitrite sample denotes the data is detected at the reported concentration, but the reported concentration is an estimate due to low MS recovery.

- The April 12, 2016, nitrate/nitrite sample result was J flagged during data validation. The nitrate/nitrite sample result was greater than the MDL and outside the MS 90\%-110\% recovery criteria per the EPA Method and the Inorganic Analyses Data Validation for INL (GDE-8511), section 4.3.9.5.4 at 115\%. The J flag for the April 12, 2016, nitrate/nitrite sample denotes the data is detected at the reported concentration, but the reported concentration is an estimate due to high MS recovery.

- The April 12, 2016, chloride sample result was J flagged during data validation. The chloride sample result was greater than the MDL and outside the MS 90\%-110\% recovery criteria per the EPA Method and the Inorganic Analyses Data Validation for INL (GDE-8511), section 4.3.9.5.4 at $120 \%$. The J flag for the April 12, 2016, chloride sample denotes the data is detected at the reported concentration, but the reported concentration is an estimate due to high MS recovery.

- The May 10, 2016, and April 12, 2016, TDS sample results were J flagged during data validation. The $\mathrm{J}$ flag denotes that TDS is detected at the reported concentration, but the reported concentration is an estimate due to the laboratory duplicate sample not meeting the relative percent difference (RPD) requirement of $\pm 5 \%$, or exhibited an absolute difference less than 5 times the reporting limit (RL) for sample and duplicate results $<20$ times the RL as outlined in GDE-8511, Section 4.3.11.6.3.

- The June 21, 2016, TKN sample result was J flagged during data validation. The TKN sample result was greater than the MDL and outside the MS 90\%-110\% recovery criteria per the EPA Method and the Inorganic Analyses Data Validation for INL (GDE-8511), section 4.3.9.5.4 at $113 \%$. The J flag for the June 21,2016 , TKN sample denotes the data is detected at the reported concentration, but the reported concentration is an estimate due to high MS recovery.

- The August 17, 2016, TKN sample result was U flagged by the laboratory and J flagged during data validation. The August 17, 2016, TKN result was assigned a UJ qualification to denote a non-detect analyte concentration that is an estimate due to a positive blank detection and high MS recovery of $113 \%$. The MS recovery for this sample was outside the $90-110 \%$ acceptance criteria.

- The September 7, 2016, TDS sample result was J flagged during data validation. The J flag denotes the TDS is detected at the reported concentration, but the reported concentration is an 
estimate due to the laboratory duplicate sample not meeting the $\pm 5 \%$ RPD requirement, as outlined in GDE-8511, Section 4.3.11.6.3.

- The October 18, 2016, TDS sample result was J flagged during data validation. The duplicate sample results were outside the $\pm 5 \%$ RPD requirements, and exhibited an absolute difference greater than 5 times the reporting limit for the sample and duplicate results greater than 20 times the reporting limit, as outlined in GDE-8511, Section 4.3.11.6.3. The J flag denotes the TDS is detected at the reported concentration, but the reported concentration is an estimate due to the high duplicate sample recovery.

\subsection{Flow Volumes and Hydraulic Loading Rates}

Daily flow readings were taken by ATR Complex CWPs Operations during the 2016 permit year, as required by Section 5.1.2 of the Reuse Permit, at the TRA-764 Cold Waste Sample Pit where the flow meter (FM-16101) is located. The flow meter measures flow to the North Pond (MU-16101) and to the South Pond (MU-16102). All flow readings were recorded in gallons per day.

Table 2 summarizes monthly and annual flow data. Daily effluent flow data is provided in Appendix A.

Table 2. Cold Waste Ponds flow summaries.

\begin{tabular}{|c|c|c|c|}
\hline Month & $\begin{array}{c}\text { North Pond } \\
(\mathrm{MU}-16101) \\
(\mathrm{MG})^{\mathrm{a}} \\
\end{array}$ & $\begin{array}{c}\text { South Pond } \\
\text { (MU-16102) } \\
\text { (MG) } \\
\end{array}$ & $\begin{array}{c}\text { Monthly Total for } \\
\text { Both Ponds } \\
\text { (MG) } \\
\end{array}$ \\
\hline November 2015 & 11.17 & 1.11 & 12.28 \\
\hline December 2015 & 0.00 & 10.88 & 10.88 \\
\hline January 2016 & 19.22 & 0.00 & 19.22 \\
\hline February 2016 & 0.63 & 11.49 & 12.12 \\
\hline March 2016 & 10.02 & 0.00 & 10.02 \\
\hline April 2016 & 1.85 & 15.77 & 17.62 \\
\hline May 2016 & 17.11 & 1.22 & 18.33 \\
\hline June 2016 & 0.00 & 16.80 & 16.80 \\
\hline July 2016 & 18.57 & 0.00 & 18.57 \\
\hline August 2016 & 0.00 & 19.27 & 19.27 \\
\hline September 2016 & 12.01 & 2.51 & 14.52 \\
\hline October 2016 & 0.75 & 10.61 & 11.36 \\
\hline Annual Total & 91.33 & 89.66 & 180.99 \\
\hline
\end{tabular}

Section 4.2 of the permit requires that the total annual volume discharged to the North and South Ponds shall not exceed a 5-year moving annual average of 300 million gallons (MG)/year. No single year shall exceed $375 \mathrm{MG} / \mathrm{yr}$. Annual hydraulic loading data from previous reporting years are used to determine compliance with the moving annual average. Figure 3 shows that the 5 -year moving average is below the permit limit. 


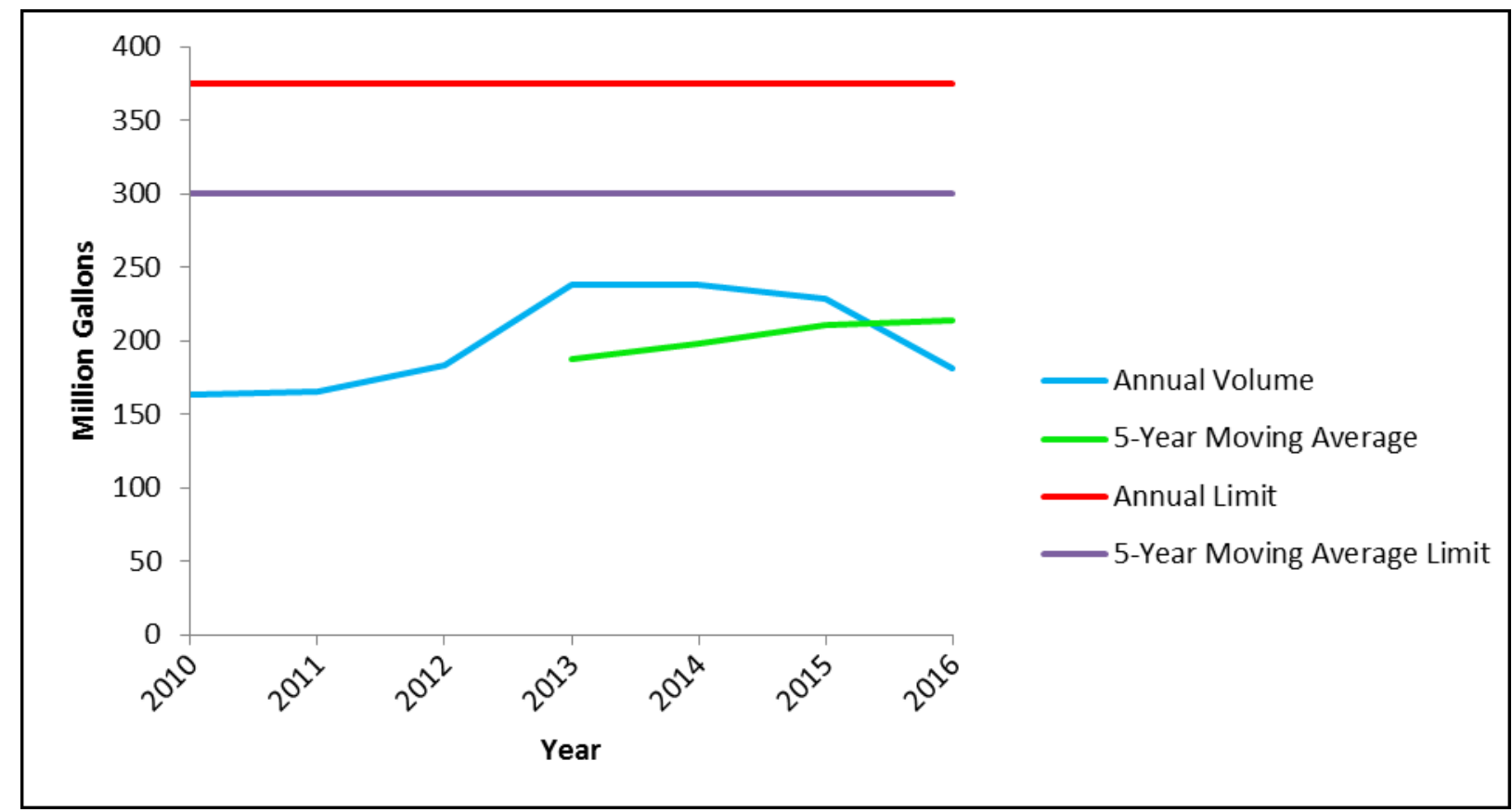

Figure 3. Advanced Test Reactor Complex Cold Waste Ponds wastewater 5-year moving average.

For permit year 2016, the total volume discharged to the North and South ponds was $91.33 \mathrm{MG}$ and 89.66 MG, respectively. The total annual volume discharged to both ponds was $180.99 \mathrm{MG}$ and significantly less than the maximum Reuse Permit annual limit of $375 \mathrm{MG}$.

\subsubsection{Flow Meter Calibration}

Calibration is performed annually and was performed on May 31, 2016, by the ATR Complex maintenance organization. The calibrations were performed to $+/-2 \%$ of full scale (full scale $=1400$ gpm). The as found calibration of the flow meter was determined to be satisfactory.

\section{GROUNDWATER MONITORING}

The groundwater monitoring sections provide information concerning the INL sampling program, analytical methods used, and monitoring results, and water table information.

\subsection{Sampling Program}

The ATR Complex CWPs Reuse Permit identifies six INL compliance wells. The permit requires that groundwater samples be collected from these six compliance wells semiannually in April or May and September or October.

The R\&MS personnel collected groundwater samples in May and September 2016. The R\&MS personnel use project-specific sampling and analysis plans and procedures that govern sampling activities and quality control protocols. The 2016 groundwater sampling was conducted in accordance with the QAPP that was submitted to DEQ on May 18, 2015 (Miller 2015a). The permit identifies a specified list of parameters that are to be analyzed in the groundwater samples. Constituent concentrations in the compliance wells are limited by primary constituent standards (PCS) and SCS specified in IDAPA 58.01.11, "Ground Water Quality Rule" with the exception of chromium. In accordance with the Reuse Permit, Section 5.2.2, footnote a., "compliance with the Primary Constituent Standard for Chromium, under this permit, shall not apply." 
As required by the Reuse Permit, unfiltered samples were collected and analyzed for nitrate + nitrite, as nitrogen, TKN, TDS, $\mathrm{pH}$, electrical conductivity, chloride, chromium, and sulfate. Filtered samples were collected and analyzed for aluminum, chromium, iron, and manganese.

Groundwater $\mathrm{pH}$ and conductivity analyses are performed at the time of sample collection by R\&MS personnel using a calibrated meter(s). All other permit required groundwater samples are submitted under full chain of custody to GEL Laboratories in Charleston, South Carolina for analysis.

\subsection{Analytical Methods}

Analytical methods specified in 40 CFR 141, "National Primary Drinking Water Regulations"; 40 CFR 143, "National Secondary Drinking Water Regulations" or 40 CFR 136, "Guidelines Establishing Test Procedures for the Analysis of Pollutants" were used for analysis of all permit-required parameters.

\subsection{Monitoring Wells}

To measure potential impacts to groundwater from the ATR Complex CWPs, the permit requires that groundwater samples be collected from six monitoring wells located in the Snake River Plain Aquifer (Figure 1):

- USGS-098 (GW-16101)

- USGS-065 (GW-16102)

- USGS-076 (GW-16104)

- TRA-08 (GW-16105)

- Middle-1823 (GW-16106)

- USGS-058 (GW-16107).

All six wells are Reuse Permit compliance points. Wells with sufficient water volume are purged to a minimum of three casing volumes or one well volume with three successive field measurements, taken not less than one minute apart, for $\mathrm{pH}$, conductivity, and temperature and meet the following conditions: temperature must be within $1^{\circ} \mathrm{C}$ of each other, and conductivity values must be within $10 \%$ of each other (LI-330).

Groundwater monitoring well TRA-07 (GW-16103) was required under the previous permit as a compliance point monitoring well. However, under the current Reuse Permit Section 5.2.1 "Ground Water Monitoring Point Descriptions" table references TRA-07 in the table's footnotes as "not required under this permit". Therefore, no samples or water level information were obtained from this well.

\subsection{Groundwater Monitoring Results}

Table 3 shows the 2016 reporting year water table elevations and depth to water table, determined prior to purging and sampling, and the analytical results for all parameters specified by the permit for the six aquifer wells. For well USGS-058, the Reuse Permit only requires sampling, analysis, and reporting of TDS and sulfate.

The permit-required parameters were below their respective Ground Water Quality Rule (IDAPA 58.01.11) PCSs or SCSs during the 2016 reporting year for all six wells.

The 2016 aluminum, iron, and manganese concentrations in the filtered samples from all five wells were significantly lower than their respective SCS. Filtered aluminum, iron and manganese concentrations in the five monitoring wells were typically below the laboratory instrument minimum detection limits or just slightly above.

Monitoring well USGS-065 is a downgradient well located southwest of the CWPs. Sulfate and TDS concentrations in this well are consistently high but less than the applicable sulfate and TDS SCS of 250 
$\mathrm{mg} / \mathrm{L}$ and $500 \mathrm{mg} / \mathrm{L}$, respectively. Sulfate and TDS concentrations were highest in the September 21, 2016 samples at $150 \mathrm{mg} / \mathrm{L}$ and $407 \mathrm{mg} / \mathrm{L}$, respectively.

Sulfate and TDS concentrations in the other five wells, including USGS-058, were significantly lower than those in well USGS-065. Well USGS-058, slightly upgradient of the North Pond, showed sulfate and TDS concentrations similar to well Middle-1823 which is the downgradient well located farthest from the CWPs.

Although some of the reported concentrations may be considered questionable, inaccurate, or imprecise, the estimated values are provided in Table 3. These qualified data are discussed below:

- For September 2016, wells USGS-065 and USGS-076 TKN sample results were assigned a J flag because the MS result was $83.1 \%$ and outside the $90 \%-110 \%$ recovery criteria, per EPA methods and GDE-8511, Section 4.3.9.5.4. Wells Middle-1823, TRA-08, and USGS-098 were assigned a UJ flag for the TKN results. The UJ flag denotes the sample concentration was below the laboratory minimum detection limit and did not meet the MS recovery criteria as discussed above.

- All September 2016, groundwater chloride and sulfate sample results were assigned a J flag during validation. The $\mathrm{J}$ flag was assigned because the reported sample concentration was less than the MDL and the MS results were outside the 90\%-110\% recovery criteria, per EPA methods and GDE-8511, Section 4.3.9.5.4. The MS recovery for chloride and sulfate were $113 \%$ and $114 \%$, respectively.

- All September 2016, groundwater iron sample results were assigned a UJ flag. The UJ flag denotes the sample concentration was below the laboratory instruments minimum detection level and the RPD of the laboratory duplicate sample result of $59.7 \%$ was above the acceptance criteria of $\pm 20 \%$, per GDE-8511, Section 4.3.11.6.2.

During the previous reporting year, the May 6, 2015, chromium sample concentration in well USGS098 was $0.149 \mathrm{mg} / \mathrm{L}$ in the unfiltered sample and above the chromium PCS of $0.1 \mathrm{mg} / \mathrm{L}$. The chromium concentration in the unfiltered sample collected on October 13, 2015, from USGS-098 was $0.0064 \mathrm{mg} / \mathrm{L}$. For 2016, all of the chromium sample results (filtered and unfiltered) were an order of magnitude lower than the PCS which supports the 2015 annual reuse report conclusion that the May 6, 2015, chromium sample concentration may have been an anomaly. Chromium concentrations in the filtered and unfiltered samples from the other four (not required for USGS-058) monitoring wells were all significantly lower than the PCS.

\subsection{Water Table Information}

Depth to water and water table elevations for the May and September, 2016 sampling events are shown in Figure 4 and Figure 5, respectively. The elevations are presented in North American Vertical Datum of 1988 (NAVD 88). In addition, the figures show the inferred general groundwater flow direction in the vicinity of the ATR Complex. In this area, the flow is in a south to southwest direction. The general groundwater flow direction at the INL Site is to the southwest. 
Table 3. Advanced Test Reactor Complex Cold Waste Ponds aquifer monitoring well data for the 2016 reporting year.

\begin{tabular}{|c|c|c|c|c|c|c|c|c|c|c|c|c|c|}
\hline \multirow{2}{*}{$\begin{array}{l}\text { WELL NAME } \\
\text { Sample Date } \\
\end{array}$} & \multicolumn{2}{|c|}{$\begin{array}{l}\text { USGS-098 } \\
\text { (GW-16101) }\end{array}$} & \multicolumn{2}{|c|}{$\begin{array}{l}\text { USGS-065 } \\
\text { (GW-16102) }\end{array}$} & \multicolumn{2}{|c|}{$\begin{array}{l}\text { USGS-076 } \\
\text { (GW-16104) }\end{array}$} & \multicolumn{2}{|c|}{$\begin{array}{c}\text { TRA-08 } \\
\text { (GW-16105) }\end{array}$} & \multicolumn{2}{|c|}{$\begin{array}{l}\text { Middle-1823 } \\
\text { (GW-16106) }\end{array}$} & \multicolumn{2}{|c|}{$\begin{array}{l}\text { USGS-058 } \\
\text { (GW-16107) }\end{array}$} & \multirow[t]{2}{*}{ PCS/SCS } \\
\hline & $05 / 10 / 16$ & $09 / 19 / 16$ & $05 / 11 / 16$ & $09 / 21 / 16$ & $05 / 11 / 16$ & $09 / 20 / 16$ & $05 / 10 / 16$ & $09 / 20 / 16$ & $05 / 10 / 16$ & $09 / 19 / 16$ & $05 / 11 / 16$ & $09 / 21 / 16$ & \\
\hline $\begin{array}{c}\text { Water Table Depth } \\
\text { (ft below ground surface) }\end{array}$ & 429.70 & 430.43 & 476.62 & 477.66 & 485.04 & 485.98 & 490.24 & 491.19 & 494.56 & 495.49 & 472.98 & 473.90 & $\mathrm{NA}^{\mathrm{b}}$ \\
\hline $\begin{array}{l}\text { Water Table Elevation } \\
\text { (above mean sea level in } \mathrm{ft})^{\mathrm{c}}\end{array}$ & 4459.69 & 4458.96 & 4451.90 & 4450.86 & 4448.17 & 4447.23 & 4448.82 & 4447.87 & 4448.31 & 4447.38 & 4448.91 & 4447.99 & $\mathrm{NA}$ \\
\hline Borehole Correction Factor $(\mathrm{ft})^{\mathrm{d}}$ & 2.53 & 2.53 & NA & NA & $\mathrm{NA}$ & NA & 0.63 & 0.63 & NA & NA & NA & NA & NA \\
\hline Nitrite + nitrate as nitrogen $(\mathrm{mg} / \mathrm{L})$ & $\begin{array}{c}1.09 \\
{[1.09]^{\mathrm{e}}}\end{array}$ & 1.1 & 1.77 & 1.45 & 1.09 & 1.02 & 1.07 & 0.975 & 1.05 & 1.01 & $\mathrm{NR}^{\mathrm{f}}$ & NR & $\mathrm{NA}$ \\
\hline Total Kjeldahl nitrogen $(\mathrm{mg} / \mathrm{L})$ & $\begin{array}{l}-0.0305 \mathrm{U}^{\mathrm{g}} \\
{[-0.0434 \mathrm{U}]}\end{array}$ & $-0.0944 \mathrm{UJ}^{\mathrm{h}}$ & $0.00679 \mathrm{U}$ & $0.0361 \mathrm{~J}^{\mathrm{i}}$ & $-0.0291 \mathrm{U}$ & $0.0387 \mathrm{~J}$ & $-0.0577 \mathrm{U}$ & $-0.0775 \mathrm{UJ}$ & $-0.0168 \mathrm{U}$ & $-0.0848 \mathrm{UJ}$ & NR & NR & $\mathrm{NA}$ \\
\hline Total nitrogen $(\mathrm{mg} / \mathrm{L})$ & $\begin{array}{c}1.09 \\
{[1.09]}\end{array}$ & 1.1 & $<1.777$ & 1.4861 & 1.09 & 1.0587 & 1.07 & 0.975 & 1.05 & 1.01 & NR & $\mathrm{NR}$ & $\mathrm{NA}$ \\
\hline pH (s.u.) & 7.84 & 7.31 & 7.94 & 7.47 & 7.98 & 7.79 & 7.86 & 7.77 & 7.90 & 7.84 & NR & NR & 6.5 to 8.5 \\
\hline Electrical conductivity $(\mu \mathrm{S} / \mathrm{cm})$ & 409 & 371 & 600 & 605 & 466 & 433 & 418 & 418 & 432 & 413 & $\mathrm{NR}$ & $\mathrm{NR}$ & NA \\
\hline Chloride (mg/L) & $\begin{array}{c}13.3 \\
{[13.3]}\end{array}$ & $14 \mathrm{~J}$ & 17 & $17.7 \mathrm{~J}$ & 11.8 & $11.9 \mathrm{~J}$ & 10.4 & $10.7 \mathrm{~J}$ & 10.3 & $10.5 \mathrm{~J}$ & NR & NR & $\begin{array}{l}250 \\
(\mathrm{SCS})\end{array}$ \\
\hline Sulfate $(\mathrm{mg} / \mathrm{L})$ & $\begin{array}{c}21.3 \\
{[21.5]}\end{array}$ & $21.7 \mathrm{~J}$ & 146 & $150 \mathrm{~J}$ & 34.3 & $34.5 \mathrm{~J}$ & 46.5 & $45.5 \mathrm{~J}$ & 35.4 & $34.8 \mathrm{~J}$ & 35.9 & $33.1 \mathrm{~J}$ & $\begin{array}{l}250 \\
\text { (SCS) }\end{array}$ \\
\hline Total dissolved solids ( $\mathrm{mg} / \mathrm{L}$ ) & $\begin{array}{c}207 \\
{[200]}\end{array}$ & 230 & 323 & 407 & 194 & 240 & 217 & 259 & 220 & 237 & 216 & 239 & $\begin{array}{c}500 \\
\text { (SCS) }\end{array}$ \\
\hline Aluminum, filtered $(\mathrm{mg} / \mathrm{L})$ & $\begin{array}{c}0.015 \mathrm{U} \\
{[0.015 \mathrm{U}]}\end{array}$ & $0.015 \mathrm{U}$ & $0.015 \mathrm{U}$ & $0.015 \mathrm{U}$ & $0.015 \mathrm{U}$ & $0.015 \mathrm{U}$ & 0.0205 & 0.0425 & $0.015 \mathrm{U}$ & $0.015 \mathrm{U}$ & NR & $\mathrm{NR}$ & $\begin{array}{c}0.2 \\
\text { (SCS) }\end{array}$ \\
\hline Chromium', total (mg/L) & $\begin{array}{l}0.00566 \\
{[0.006]}\end{array}$ & 0.00688 & 0.0747 & 0.082 & 0.011 & 0.0114 & 0.0285 & 0.0683 & 0.00923 & 0.0102 & NR & $\mathrm{NR}$ & $\begin{array}{c}0.1 \\
\text { (PCS) }\end{array}$ \\
\hline Chromium', filtered (mg/L) & $\begin{array}{c}0.00581 \\
{[0.00602]}\end{array}$ & 0.0062 & 0.0751 & 0.0801 & 0.0115 & 0.0111 & 0.0183 & 0.0197 & 0.00919 & 0.0104 & NR & NR & $\begin{array}{c}0.1 \\
\text { (PCS) }\end{array}$ \\
\hline Iron, filtered $(\mathrm{mg} / \mathrm{L})$ & $\begin{array}{c}0.030 \mathrm{U} \\
{[0.030 \mathrm{U}]}\end{array}$ & $0.030 \mathrm{UJ}$ & $0.030 \mathrm{U}$ & $0.030 \mathrm{UJ}$ & $0.030 \mathrm{U}$ & $0.030 \mathrm{UJ}$ & $0.030 \mathrm{U}$ & $0.03 \mathrm{UJ}$ & $0.030 \mathrm{U}$ & $0.030 \mathrm{UJ}$ & NR & NR & $\begin{array}{l}0.3 \\
\text { (SCS) }\end{array}$ \\
\hline Manganese, filtered $(\mathrm{mg} / \mathrm{L})$ & $\begin{array}{c}0.001 \mathrm{U} \\
{[0.001 \mathrm{U}]}\end{array}$ & $0.001 \mathrm{U}$ & $0.001 \mathrm{U}$ & $0.001 \mathrm{U}$ & $0.001 \mathrm{U}$ & $0.001 \mathrm{U}$ & $0.001 \mathrm{U}$ & $0.001 \mathrm{U}$ & 0.00155 & 0.00267 & NR & NR & $\begin{array}{l}0.05 \\
\text { (SCS) }\end{array}$ \\
\hline $\begin{array}{l}\text { a. Primary constituent standards (PCS) and sec } \\
\text { b. NA- Not applicable. } \\
\text { c. Elevation data provided using the North Am } \\
\text { d. The United States Geological Survey perfor } \\
\text { table. The water table elevations for these two } \\
\text { e. Results shown in brackets are the results fro } \\
\text { f. NR indicates the parameter is not required b } \\
\text { g. Uflag indicates that the result was reported } \\
\text {.h UJ flag indicates the sample was analyzed f } \\
\text { i. J flag indicates the associated value is an est } \\
\text { j. Total nitrogen is calculated as the sum of the }\end{array}$ & $\begin{array}{l}\text { have been adjus } \\
\text { d duplicate samt } \\
\text { Reuse Permit. } \\
\text { ow the instrume } \\
\text { twas not detecte } \\
\text { and may be inac } \\
\text { Kjeldahl nitroge } \\
\text { eported as a less }\end{array}$ & $\begin{array}{l}\text { ion limit by th } \\
\text { sociated valu } \\
\text { simprecise. } \\
\text { sand notrite } \\
\text { number. } \\
\text { num }\end{array}$ & $\begin{array}{l}\text { ical laborat } \\
\text { stimate and }\end{array}$ & ccurate or in & 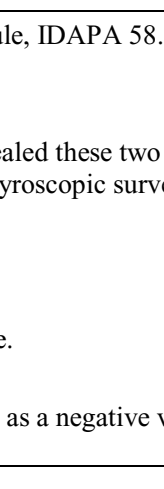 &  & 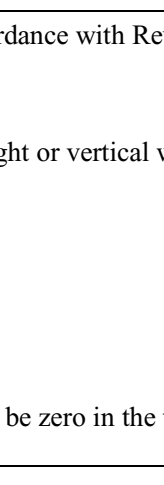 & . & ( & 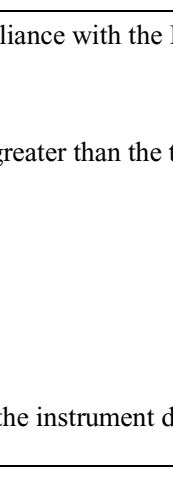 &  & 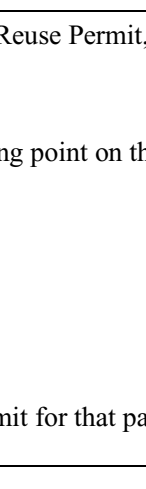 & $\begin{array}{l}\text { ta apply. } \\
\text { the water } \\
\text { is used in }\end{array}$ \\
\hline
\end{tabular}







Figure 4. Map showing depths and elevations based on the May 2016 water level measurements. 


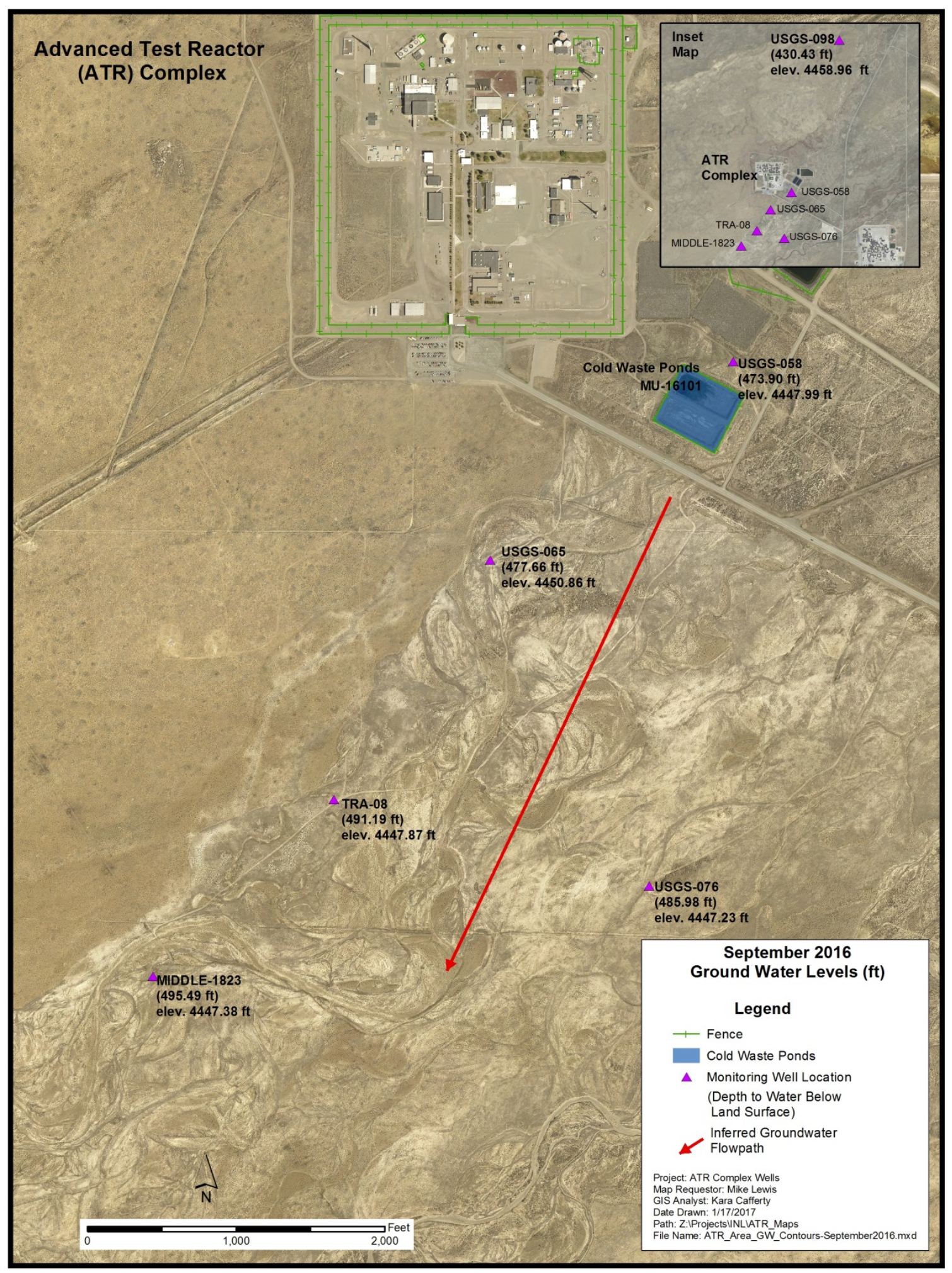

Figure 5. Map showing depths and elevations based on the September 2016 water level measurements. 


\section{PERMIT YEAR SUMMARIES}

This section provides information and status associated with permit required compliance activities and noncompliance issues.

\subsection{Status of Permit Required Compliance Activities}

Section 3 of the Reuse Permit identifies four compliance activities (CA-161-01 through 04) discussed below:

CA-161-01 - Within 12 months of permit issuance, the permittee shall submit for review and approval a Plan of Operation (PO) that reflects current operations and incorporates the requirements of the Reuse Permit. The PO shall be updated as needed to reflect current operations. The permittee shall notify DEQ of material changes to the PO and copies shall be kept on site and made available to DEQ upon request.

The PO was submitted to DEQ on November 19, 2015 (Miller 2015b). Approval of the PO from DEQ has not been received.

CA-161-02 - Within 6 months of permit issuance, the permittee is required to prepare and implement a Quality Assurance Project Plan (QAPP) that incorporates all monitoring and reporting required by the permit. A copy of the QAPP and a written notice that the QAPP has been implemented shall be provided to DEQ.

A copy of the QAPP and the implementation notice were submitted to DEQ on May 18, 2015 (Miller 2015a).

CA-161-03 - Twelve months prior to permit expiration, the permittee shall contact DEQ and schedule a pre-application workshop to discuss the compliance status of the facility and the content required for the reuse permit application package.

This requirement has been added to the INL electronic Commitment Tracking System (CTS). This system provides automatic reminders to those responsible for completing the action. The first reminder date for this activity is May 18, 2018.

CA-161-04 - Six months prior to permit expiration the permittee shall submit to DEQ a complete permit renewal application package, which fulfills the requirements specified at the pre-application workshop identified in CA-161-03.

The first CTS reminder date for this activity is also May 18, 2018.

\subsection{Noncompliance/lssues}

There were no permit noncompliances for the 2016 reporting year. However, there was an issue with a non-contact cooling water leak.

On June 8,2016, at the ATR Complex, water was discovered ponding through cracks in the pavement near building TRA-614 (Office Building/Bunkhouse). The water was first suspected to be a leak in the lawn sprinkler system. On June 13, 2016, after further investigation, it was determined the leak was coming from a 2" Cold Waste system service connection to TRA-614, although there are no cold waste water sources in TRA-614. However, there is a 2" Cold Waste system service connection from TRA-628 (Engineering Office Building) that connects into the service connection from TRA-614. From this point, the line runs approximately 170' before tying into a 10" Cold Waste system line. It was suspected that there was a restriction in this 2 " drain line prior to where it ties into the 10 " line, causing non-contact cooling water from the heat pumps in TRA- 628 to backup into the TRA-614 service connection. 
Operations personnel verified TRA-628 as the water source by isolating the non-contact cooling water supply for the TRA-628 heat pumps. Once isolated, the water on the surface began to dry up. Approximately 50 to 55 gpm of non-contact cooling water was flowing through the heat pumps. The volume from the leak is unknown, but it was estimated that approximately one gpm or less was observed leaking at the surface and no evidence of sink holes in the area. The only pollutant added to the noncontact cooling water is heat. Other than the non-contact cooling water from the heat pumps, there are no other water sources in building TRA-628 that discharge into the 2" Cold Waste system service connection.

On July 14, 2016, the location of the leak was excavated. It was confirmed the source of the leak was non-contact cooling water for TRA-628 from a section of pipe in the service connection for TRA-614. Approximately two feet of pipe was removed. Soft plugs were installed upstream and downstream of the service connection (Lewis 2016).

A camera inspection in both the upstream and downstream legs of the TRA-614 service connection was performed on July 18, 2016. The upstream section of pipe appeared to be blocked by either corrosion or a plug. The camera inspection was repeated on August 1,2016. The upstream leg of the pipe was found to be capped approximately 12.75 feet upstream from the removed section of pipe. The downstream leg did not appear to have any restriction or corrosion similar to the section of pipe removed (Lewis 2016).

Welding permanent blanks on both the upstream and downstream legs of the service connection, thus permanently isolating TRA-614 from the Cold Waste system, was proposed to DEQ. The DEQ agreed this approach was acceptable and that engineering plans and specifications were not required to be submitted to DEQ for review and approval (Rackow 2016). The isolation was completed on August 26, 2016.

\subsection{Department of Environmental Quality Annual Inspection}

On October 12, 2016, personnel from the DEQ Boise office inspected the ATR Complex CWPs to determine compliance with Reuse Permit No. I-161-02. DEQ found the ATR Complex CWPs in substantial compliance with the Reuse Permit (John 2016).

Reuse facilities and structures visited during the inspection included monitoring well USGS-098, TRA-703 (Cold Waste Sump Pit), TRA-764 (Cold Waste Sampling Pit), and the CWPs. Current operations were discussed including a planned future upgrade to the pump system, flow meter calibration date, dates and timing for switching flow to the ponds, monitoring activities, laboratory used for sample analysis, etc. DEQ reviewed laboratory and data validation reports.

DEQ provided two recommendations:

1. INL should contact the Idaho Falls Regional Office to discuss the interpretation of Item 8 in Section 6.1 .2 of the Reuse Permit. This section requires "All laboratory analytical reports and chain of custody forms" are to be submitted in the annual report.

2. "The facility should continue to update DEQ on the progress of the installation of a new control system for the pumps."

\section{ENVIRONMENTAL IMPACTS}

The Reuse Permit allows 300 MG/year as a 5-year annual average, not to exceed 375 MG annually. The total volume discharged to the CWPs for this period (November 1, 2015-October 31, 2016) was 180.99 MG. No runoff occurred from the application area.

Total nitrogen concentrations in the effluent ranged between $0.879 \mathrm{mg} / \mathrm{L}$ in the February 2016 sample to $5.02 \mathrm{mg} / \mathrm{L}$ in the March 2016 sample (Table 1). Nitrogen can be lost or removed from the soil by

leaching, ammonia volatilization, and denitrification. Total nitrogen in the nearest downgradient well 
(USGS-065) from the CWPs was less than $1.777 \mathrm{mg} / \mathrm{L}$ in the May 2016 sample and $1.4861 \mathrm{mg} / \mathrm{L}$ in the September 2016 sample. The upgradient well (USGS-098) had total nitrogen (TN) concentrations in the May and September 2016 samples of $1.09 \mathrm{mg} / \mathrm{L}$ and $1.1 \mathrm{mg} / \mathrm{L}$, respectively. The impact of TN on the groundwater from the CWPs appears to be minimal.

Sulfate and TDS concentrations (Table 1) in the effluent have the potential to impact groundwater. Sulfate has high solubility and tends to move at a similar velocity as the groundwater (DEQ 2007). Sulfate and TDS sampling began in 2015 for wells USGS-098 and USGS-058. Sampling wells USGS098 and USGS-058 was not required by the previous permit.

Sulfate concentrations in the 2016 permit year effluent monthly samples ranged from a low of $20.1 \mathrm{mg} / \mathrm{L}$ in the April 2016 sample to a high of $628 \mathrm{mg} / \mathrm{L}$ in the March 2016 sample. The TDS effluent concentrations ranged from a low of $189 \mathrm{mg} / \mathrm{L}$ in the April 2016 sample to a high of $1,300 \mathrm{mg} / \mathrm{L}$ in the March 2016 sample. There are no Reuse Permit effluent limits for sulfate and TDS. However, as discussed below, there are groundwater quality standards for these two parameters.

Figures 6 and 7 show the sulfate and TDS concentrations in samples collected from the Reuse Permit CWPs monitoring wells. Sulfate and TDS data were not available for Well TRA-08 for October 2009 due to insufficient water available to collect a representative sample. Where a duplicate sample was collected, the average of the original sample and the duplicate sample were used in generating the graphs.

Well USGS-065 has the highest sulfate concentrations of the six monitoring wells (Figure 6). Of the six wells, USGS-065 is the closest downgradient well to the CWPs. As shown in Figure 6, the sulfate concentration in well USGS-065 has remained below the SCS of $250 \mathrm{mg} / \mathrm{L}$.



Figure 6. Sulfate concentrations in the Cold Waste Ponds monitoring wells. 
Similar to sulfate, the highest TDS concentration is in well USGS-065 (Figure 7). The highest TDS concentration in USGS-065 occurred in April 2012 at $471 \mathrm{mg} / \mathrm{L}$. The TDS concentration in USGS-065 has remained below the SCS of $500 \mathrm{mg} / \mathrm{L}$ (Figure 7).

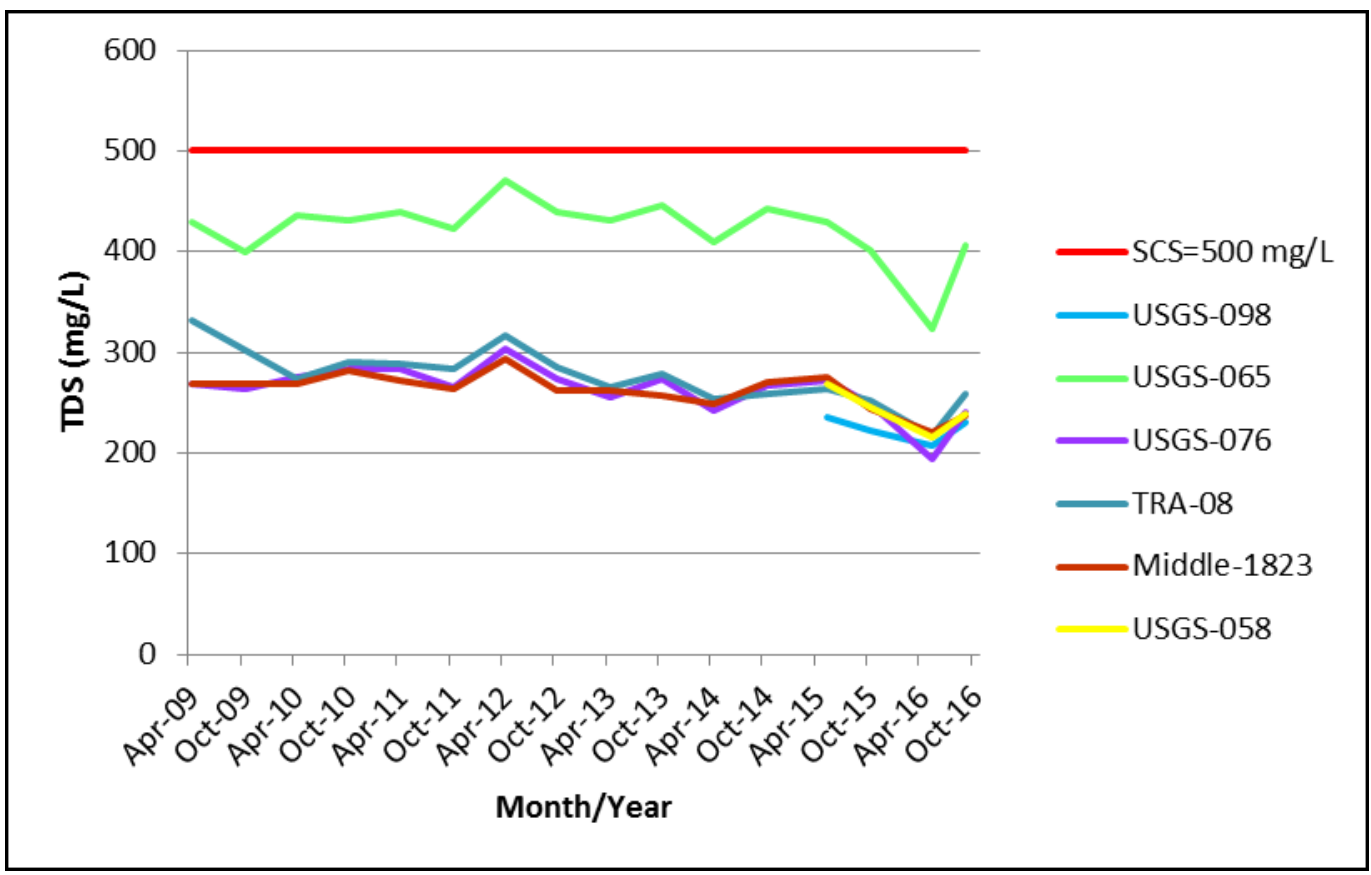

Figure 7. Total dissolved solids concentrations in the Cold Waste Ponds monitoring wells.

A Mann-Kendall trend analysis was performed on sulfate and TDS in the groundwater wells. Sulfate concentrations were found to be stable in wells USGS-058, USGS-098, and Middle-1823 at the 90\% confidence level (Table 4). The sulfate trend appears to be decreasing in wells TRA-08 and USGS-065 but increasing in well USGS-076 at the $90 \%$ confidence level.

In groundwater wells Middle-1823, TRA-08, USGS-065, and USGS-076, there appears to be a decreasing trend in TDS concentrations at the 90\% confidence level (Table 5). For wells USGS-058 and USGS-098, the analysis shows there is no trend for TDS at the $90 \%$ confidence level (Table 5).

Table 4. Mann-Kendall trend analysis results for sulfate in the groundwater monitoring wells.

\begin{tabular}{|l|c|c|c|c|}
\hline Well Name & \# Samples & $\begin{array}{c}\text { Trend } \geq \mathbf{8 0 \%} \\
\text { Confidence }\end{array}$ & $\begin{array}{c}\text { Trend } \geq \mathbf{9 0 \%} \\
\text { Confidence }\end{array}$ & $\begin{array}{c}\text { Stability Check } \\
\text { (if no trend at } 80 \% \\
\text { confidence) }\end{array}$ \\
\hline USGS-098 & 4 & No Trend & No Trend & Stable \\
\hline USGS-065 & 10 & Decreasing & Decreasing & NA $^{\text {a }}$ \\
\hline USGS-076 & 10 & Increasing & Increasing & NA \\
\hline TRA-08 & 10 & Decreasing & Decreasing & NA \\
\hline Middle-1823 & 10 & No Trend & No Trend & Stable \\
\hline USGS-058 & 4 & No Trend & No Trend & \\
\hline a. Not applicable. &
\end{tabular}


Table 5. Mann-Kendall trend analysis results for total dissolved solids in the groundwater monitoring wells.

\begin{tabular}{|l|c|c|c|c|}
\hline Well Name & \# Samples & $\begin{array}{c}\text { Trend } \geq \mathbf{8 0 \%} \\
\text { Confidence }\end{array}$ & $\begin{array}{c}\text { Trend } \geq \mathbf{9 0 \%} \\
\text { Confidence }\end{array}$ & Stability Check \\
\hline USGS-098 & 4 & No Trend & No Trend & Stable \\
\hline USGS-065 & 10 & Decreasing & Decreasing & NA $^{\text {a }}$ \\
\hline USGS-076 & 10 & Decreasing & Decreasing & NA \\
\hline TRA-08 & 10 & Decreasing & Decreasing & NA \\
\hline Middle-1823 & 10 & Decreasing & Decreasing & NA \\
\hline USGS-058 & 4 & Decreasing & No Trend & \\
\hline a. Not applicable.
\end{tabular}

With the exception of USGS-065, sulfate and TDS concentrations in the groundwater wells (Figures 6 and 7) are only slightly elevated when compared to the concentrations in background well USGS-098. The sulfate and TDS quickly dissipate with distance from the ponds. This can be seen when comparing the 2016 permit year sulfate and TDS concentrations found in Wells USGS-065 and Middle-1823 (Figures 6 and 7). Well USGS-065, located approximately 1,200 ft downgradient of the CWPs, had a maximum sulfate concentration of $150 \mathrm{mg} / \mathrm{L}$ and a TDS concentration of $407 \mathrm{mg} / \mathrm{L}$. Well Middle-1823, located approximately 4,000 ft downgradient from the CWPs, had maximum sulfate and TDS concentrations of $35.4 \mathrm{mg} / \mathrm{L}$ and $237 \mathrm{mg} / \mathrm{L}$, respectively. The concentrations of sulfate and TDS in Well Middle-1823 are similar to the concentrations in the up/cross gradient Well USGS-076 (Figures 6 and 7).

As stated above, sulfate and TDS have SCSs for groundwater quality. The SCSs are generally based on aesthetic qualities including odor, taste, color, and foaming (EPA 1992). Sulfate is listed for causing a "salty taste" in drinking water. Total dissolved solids are listed for "hardness, deposits, colored water, staining, and salty taste." The nearest drinking water well is located approximately 3 miles downgradient of the CWPs. Because the higher levels of sulfate and TDS are localized near the CWPs and their SCSs are based on aesthetics, impacts to human health and the environment are expected to be minimal.

Groundwater sample results for aluminum, chromium, iron, and manganese, in wells USGS-065, USGS-076, TRA-08, and Middle-1823, were significantly lower than the applicable PCS or SCS (Table 3).

There are positive impacts to the environment associated with the operation of the CWPs. These include returning a significant portion of the industrial wastewater to the aquifer and providing needed water for several native animal species in an otherwise semi-arid environment. 


\section{REFERENCES}

40 CFR 136, "Guidelines Establishing Test Procedures for the Analysis of Pollutants," Code of Federal Regulations, Office of the Federal Register, July 2016.

40 CFR 141, "National Primary Drinking Water Regulations," Code of Federal Regulations, Office of the Federal Register, July 2016.

40 CFR 143, "National Secondary Drinking Water Regulations," Code of Federal Regulations, Office of the Federal Register, July 2016.

DEQ, 2007, Guidance for Reclamation and Reuse of Municipal and Industrial Wastewater, Idaho Department of Environmental Quality, September 2007.

EPA, 1992, Secondary Drinking Water Regulations: Guidance for Nuisance Chemicals, EPA 810/K-92-001.

GDE-8511, “Inorganic Analyses Data Validation for INL,” Revision 0, January 25, 2007.

IDAPA 58.01.11, 2016, “Ground Water Quality Rule,” Idaho Department of Environmental Quality, March 2016.

John, A., DEQ, to T. A. Miller, INL, October 24, 2016, “I-161-02 INL ATR Cold Waste Ponds, 2016 Inspection," CCN 239279.

Lewis, M. G., INL, to T. Rackow, DEQ, August 3, 2016, "Response to DEQ Request Concerning NonContact Cooling Water Leak at the Advanced Test Reactor Complex," CCN 238534.

LI-330, 2015, "Groundwater Monitoring for the Advanced Test Reactor Complex Cold Waste Pond Industrial Wastewater Reuse Permit," Revision 4, February 27, 2015.

Miller, T. A., INL, to G. Eager, DEQ, May 18, 2015a, "Reuse Permit I-161-02 Compliance Activity CA161-02 Quality Assurance Project Plan Transmittal," CCN 235805.

Miller, T. A., INL, to G. Eager, DEQ, November 19, 2015b, "Reuse Permit I-160-02 Compliance Activity CA-161-01 Plan of Operation Transmittal," CCN 237051.

Neher, E., DEQ, to R. Boston, DOE-ID, November 20, 2014, "I-161-02 INL ATR Cold Waste Ponds, Final Permit," CCN 234522.

Rackow, T., DEQ, to M. G. Lewis, INL, August 3, 2016, "Response to DEQ Request Concerning NonContact Cooling Water Leak at the Advanced Test Reactor Complex," CCN 238534. 


\section{Appendix A}

\section{Daily Discharge Volumes to the Advanced Test Reactor Complex Cold Waste Ponds}




\section{Appendix A}

\section{Daily Discharge Volumes to the Advanced Test Reactor Complex Cold Waste Ponds}

Table A-1. Daily discharge volumes to the ATR Complex CWPs for the 2016 permit year.

\begin{tabular}{|c|c|c|c|c|c|}
\hline Date & $\begin{array}{l}\text { North Pond } \\
\text { (gal) }\end{array}$ & $\begin{array}{c}\text { South Pond } \\
\text { (gal) }\end{array}$ & Date & $\begin{array}{c}\text { North Pond } \\
\text { (gal) }\end{array}$ & $\begin{array}{c}\text { South Pond } \\
\text { (gal) }\end{array}$ \\
\hline $11 / 01 / 15$ & OOS & 577,940 & $12 / 10 / 15$ & OOS & 344,080 \\
\hline $11 / 02 / 15$ & OOS & 527,770 & $12 / 11 / 15$ & OOS & 347,300 \\
\hline $11 / 03 / 15$ & 584,760 & OOS & $12 / 12 / 15$ & OOS & 345,700 \\
\hline $11 / 04 / 15$ & 634,430 & OOS & $12 / 13 / 15$ & OOS & 337,400 \\
\hline $11 / 05 / 15$ & 426,000 & OOS & $12 / 14 / 15$ & OOS & 384,150 \\
\hline $11 / 06 / 15$ & 693,400 & OOS & $12 / 15 / 15$ & OOS & 334,410 \\
\hline $11 / 07 / 15$ & 480,540 & OOS & $12 / 16 / 15$ & OOS & 392,440 \\
\hline $11 / 08 / 15$ & 499,500 & OOS & $12 / 17 / 15$ & OOS & 352,200 \\
\hline $11 / 09 / 15$ & 650,650 & OOS & $12 / 18 / 15$ & OOS & 343,400 \\
\hline $11 / 10 / 15$ & 700,190 & OOS & $12 / 19 / 15$ & OOS & 356,300 \\
\hline $11 / 11 / 15$ & 543,260 & OOS & $12 / 20 / 15$ & OOS & 386,250 \\
\hline $11 / 12 / 15$ & 289,020 & OOS & $12 / 21 / 15$ & OOS & 289,930 \\
\hline $11 / 13 / 15$ & 289,140 & OOS & $12 / 22 / 15$ & OOS & 359,270 \\
\hline $11 / 14 / 15$ & 353,890 & OOS & $12 / 23 / 15$ & OOS & 342,960 \\
\hline $11 / 15 / 15$ & 349,340 & OOS & $12 / 24 / 15$ & OOS & 339,880 \\
\hline $11 / 16 / 15$ & 330,980 & OOS & $12 / 25 / 15$ & OOS & 354,410 \\
\hline $11 / 17 / 15$ & 349,480 & OOS & $12 / 26 / 15$ & OOS & 346,000 \\
\hline $11 / 18 / 15$ & 334,750 & OOS & $12 / 27 / 15$ & OOS & 345,000 \\
\hline $11 / 19 / 15$ & 378,600 & OOS & $12 / 28 / 15$ & OOS & 349,500 \\
\hline $11 / 20 / 15$ & 345,500 & OOS & $12 / 29 / 15$ & OOS & 378,000 \\
\hline $11 / 21 / 15$ & 335,000 & OOS & $12 / 30 / 15$ & OOS & 336,000 \\
\hline $11 / 22 / 15$ & 333,900 & OOS & $12 / 31 / 15$ & OOS & 364,960 \\
\hline $11 / 23 / 15$ & 260,300 & OOS & $01 / 01 / 16$ & 434,030 & OOS \\
\hline $11 / 24 / 15$ & 279,900 & OOS & $01 / 02 / 16$ & 733,710 & OOS \\
\hline $11 / 25 / 15$ & 281,900 & OOS & $01 / 03 / 16$ & 593,910 & OOS \\
\hline $11 / 26 / 15$ & 286,180 & OOS & $01 / 04 / 16$ & 545,740 & OOS \\
\hline $11 / 27 / 15$ & 275,530 & OOS & $01 / 05 / 16$ & 593,600 & OOS \\
\hline $11 / 28 / 15$ & 263,300 & OOS & $01 / 06 / 16$ & 623,760 & OOS \\
\hline $11 / 29 / 15$ & 268,760 & OOS & $01 / 07 / 16$ & 605,600 & OOS \\
\hline $11 / 30 / 15$ & 349,390 & OOS & $01 / 08 / 16$ & 502,680 & OOS \\
\hline $12 / 01 / 15$ & OOS & 329,040 & $01 / 09 / 16$ & 664,500 & OOS \\
\hline $12 / 02 / 15$ & OOS & 365,010 & $01 / 10 / 16$ & 463,610 & OOS \\
\hline $12 / 03 / 15$ & OOS & 373,580 & $01 / 11 / 16$ & 698,430 & OOS \\
\hline $12 / 04 / 15$ & OOS & 355,180 & $01 / 12 / 16$ & 635,010 & OOS \\
\hline $12 / 05 / 15$ & OOS & 346,090 & $01 / 13 / 16$ & 760,060 & OOS \\
\hline $12 / 06 / 15$ & OOS & 354,950 & $01 / 14 / 16$ & 619,050 & OOS \\
\hline $12 / 07 / 15$ & OOS & 325,870 & $01 / 15 / 16$ & 569,550 & OOS \\
\hline $12 / 08 / 15$ & OOS & 362,530 & $01 / 16 / 16$ & 669,300 & OOS \\
\hline $12 / 09 / 15$ & OOS & 333,810 & $01 / 17 / 16$ & 619,250 & OOS \\
\hline
\end{tabular}




\begin{tabular}{|c|c|c|}
\hline Date & $\begin{array}{l}\text { North Pond } \\
\text { (gal) }\end{array}$ & $\begin{array}{l}\text { South Pond } \\
\text { (gal) }\end{array}$ \\
\hline $01 / 18 / 16$ & 615,850 & OOS \\
\hline $01 / 19 / 16$ & 718,270 & OOS \\
\hline $01 / 20 / 16$ & 641,390 & OOS \\
\hline $01 / 21 / 16$ & 841,080 & OOS \\
\hline $01 / 22 / 16$ & 578,500 & OOS \\
\hline $01 / 23 / 16$ & 655,200 & OOS \\
\hline $01 / 24 / 16$ & 614,070 & OOS \\
\hline $01 / 25 / 16$ & 667,090 & OOS \\
\hline $01 / 26 / 16$ & 620,840 & OOS \\
\hline $01 / 27 / 16$ & 619,450 & OOS \\
\hline $01 / 28 / 15$ & 576,180 & OOS \\
\hline $01 / 29 / 16$ & 610,020 & OOS \\
\hline $01 / 30 / 16$ & 480,530 & OOS \\
\hline $01 / 31 / 16$ & 654,530 & OOS \\
\hline $02 / 01 / 16$ & 633,300 & OOS \\
\hline $02 / 02 / 16$ & OOS & 655,590 \\
\hline $02 / 03 / 16$ & OOS & 681,860 \\
\hline $02 / 04 / 16$ & OOS & 673,160 \\
\hline $02 / 05 / 16$ & OOS & 635,580 \\
\hline $02 / 06 / 16$ & OOS & 704,160 \\
\hline $02 / 07 / 16$ & OOS & 731,250 \\
\hline $02 / 08 / 16$ & OOS & 630,570 \\
\hline $02 / 09 / 16$ & OOS & 558,060 \\
\hline $02 / 10 / 16$ & OOS & 205,520 \\
\hline $02 / 11 / 16$ & OOS & 274,900 \\
\hline $02 / 12 / 16$ & OOS & 369,700 \\
\hline $02 / 13 / 16$ & OOS & 340,900 \\
\hline $02 / 14 / 16$ & OOS & 323,200 \\
\hline $02 / 15 / 16$ & OOS & 273,730 \\
\hline $02 / 16 / 16$ & OOS & 264,370 \\
\hline $02 / 17 / 16$ & OOS & 315,770 \\
\hline $02 / 18 / 16$ & OOS & 274,040 \\
\hline $02 / 19 / 16$ & OOS & 253,370 \\
\hline $02 / 20 / 16$ & OOS & 297,760 \\
\hline $02 / 21 / 16$ & OOS & 251,470 \\
\hline $02 / 22 / 16$ & OOS & 343,290 \\
\hline $02 / 23 / 16$ & OOS & 358,200 \\
\hline $02 / 24 / 16$ & OOS & 400,650 \\
\hline $02 / 25 / 16$ & OOS & 323,150 \\
\hline $02 / 26 / 16$ & OOS & 322,280 \\
\hline $02 / 27 / 16$ & OOS & 353,550 \\
\hline $02 / 28 / 16$ & OOS & 332,220 \\
\hline $02 / 29 / 16$ & OOS & 338,020 \\
\hline $03 / 01 / 16$ & 327,610 & OOS \\
\hline $03 / 02 / 16$ & 347,220 & OOS \\
\hline $03 / 03 / 16$ & 439,130 & OOS \\
\hline
\end{tabular}

\begin{tabular}{|c|c|c|}
\hline Date & $\begin{array}{c}\text { North Pond } \\
\text { (gal) }\end{array}$ & $\begin{array}{c}\text { South Pond } \\
\text { (gal) }\end{array}$ \\
\hline $03 / 04 / 16$ & 255,080 & OOS \\
\hline $03 / 05 / 16$ & 378,080 & OOS \\
\hline $03 / 06 / 16$ & 363,400 & OOS \\
\hline $03 / 07 / 16$ & 274,610 & OOS \\
\hline $03 / 08 / 16$ & 270,700 & OOS \\
\hline $03 / 09 / 16$ & 246,500 & OOS \\
\hline $03 / 10 / 16$ & 316,370 & OOS \\
\hline $03 / 11 / 16$ & 227,150 & OOS \\
\hline $03 / 12 / 16$ & 285,830 & OOS \\
\hline $03 / 13 / 16$ & 276,450 & OOS \\
\hline $03 / 14 / 16$ & 365,170 & OOS \\
\hline $03 / 15 / 16$ & 312,130 & OOS \\
\hline $03 / 16 / 16$ & 347,800 & OOS \\
\hline $03 / 17 / 16$ & 383,390 & OOS \\
\hline $03 / 18 / 16$ & 334,800 & OOS \\
\hline $03 / 19 / 16$ & 314,390 & OOS \\
\hline $03 / 20 / 16$ & 327,230 & OOS \\
\hline $03 / 21 / 16$ & 361,090 & OOS \\
\hline $03 / 22 / 16$ & 346,320 & OOS \\
\hline $03 / 23 / 16$ & 338,160 & OOS \\
\hline $03 / 24 / 16$ & 380,120 & OOS \\
\hline $03 / 25 / 16$ & 375,020 & OOS \\
\hline $03 / 26 / 16$ & 327,670 & OOS \\
\hline $03 / 27 / 16$ & 343,510 & OOS \\
\hline $03 / 28 / 16$ & 405,410 & OOS \\
\hline $03 / 29 / 16$ & 270,400 & OOS \\
\hline $03 / 30 / 16$ & 232,230 & OOS \\
\hline $03 / 31 / 16$ & 245,170 & OOS \\
\hline $04 / 01 / 16$ & 731,540 & OOS \\
\hline $04 / 02 / 16$ & 533,750 & OOS \\
\hline $04 / 03 / 16$ & 588,720 & OOS \\
\hline $04 / 04 / 16$ & OOS & 600,880 \\
\hline $04 / 05 / 16$ & OOS & 862,600 \\
\hline $04 / 06 / 16$ & OOS & 628,370 \\
\hline $04 / 07 / 16$ & OOS & 577,000 \\
\hline $04 / 08 / 16$ & OOS & 598,900 \\
\hline $04 / 09 / 16$ & OOS & 591,700 \\
\hline $04 / 10 / 16$ & OOS & 551,130 \\
\hline $04 / 11 / 16$ & OOS & 631,550 \\
\hline $04 / 12 / 16$ & OOS & 500,550 \\
\hline $04 / 13 / 16$ & OOS & 579,900 \\
\hline $04 / 14 / 16$ & OOS & 611,710 \\
\hline $04 / 15 / 16$ & OOS & 590,630 \\
\hline $04 / 16 / 16$ & OOS & 586,740 \\
\hline $04 / 17 / 16$ & OOS & 525,720 \\
\hline $04 / 18 / 16$ & OOS & 620,600 \\
\hline
\end{tabular}




\begin{tabular}{|c|c|c|}
\hline Date & $\begin{array}{l}\text { North Pond } \\
\text { (gal) }\end{array}$ & $\begin{array}{l}\text { South Pond } \\
\text { (gal) }\end{array}$ \\
\hline $04 / 19 / 16$ & OOS & 592,620 \\
\hline $04 / 20 / 16$ & OOS & 583,600 \\
\hline $04 / 21 / 16$ & OOS & 655,790 \\
\hline $04 / 22 / 16$ & OOS & 571,330 \\
\hline $04 / 23 / 16$ & OOS & 588,710 \\
\hline $04 / 24 / 16$ & OOS & 585,450 \\
\hline $04 / 25 / 16$ & OOS & 603,070 \\
\hline $04 / 26 / 16$ & OOS & 531,690 \\
\hline $04 / 27 / 16$ & OOS & 238,440 \\
\hline $04 / 28 / 16$ & OOS & 590,000 \\
\hline $04 / 29 / 16$ & OOS & 670,690 \\
\hline $04 / 30 / 16$ & OOS & 501,950 \\
\hline $05 / 01 / 16$ & OOS & 647,050 \\
\hline $05 / 02 / 16$ & OOS & 575,110 \\
\hline $05 / 03 / 16$ & 596,990 & OOS \\
\hline $05 / 04 / 16$ & 615,790 & OOS \\
\hline $05 / 05 / 16$ & 721,450 & OOS \\
\hline $05 / 06 / 16$ & 464,690 & OOS \\
\hline $05 / 07 / 16$ & 636,880 & OOS \\
\hline $05 / 08 / 16$ & 679,660 & OOS \\
\hline $05 / 09 / 16$ & 489,740 & OOS \\
\hline $05 / 10 / 16$ & 621,370 & OOS \\
\hline $05 / 11 / 16$ & 620,760 & OOS \\
\hline $05 / 12 / 16$ & 681,790 & OOS \\
\hline $05 / 13 / 16$ & 497,800 & OOS \\
\hline $05 / 14 / 16$ & 616,400 & OOS \\
\hline $05 / 15 / 16$ & 554,080 & OOS \\
\hline $05 / 16 / 16$ & 562,380 & OOS \\
\hline $05 / 17 / 16$ & 665,220 & OOS \\
\hline $05 / 18 / 16$ & 509,500 & OOS \\
\hline $05 / 19 / 16$ & 653,800 & OOS \\
\hline $05 / 20 / 16$ & 631,370 & OOS \\
\hline $05 / 21 / 16$ & 568,500 & OOS \\
\hline $05 / 22 / 16$ & 542,890 & OOS \\
\hline $05 / 23 / 16$ & 564,910 & OOS \\
\hline $05 / 24 / 16$ & 565,340 & OOS \\
\hline $05 / 25 / 16$ & 624,820 & OOS \\
\hline $05 / 26 / 16$ & 668,980 & OOS \\
\hline $05 / 27 / 16$ & 544,430 & OOS \\
\hline $05 / 28 / 16$ & 534,770 & OOS \\
\hline $05 / 29 / 16$ & 581,960 & OOS \\
\hline $05 / 30 / 16$ & 488,730 & OOS \\
\hline $05 / 31 / 16$ & 602,800 & OOS \\
\hline $06 / 01 / 16$ & OOS & 504,390 \\
\hline $06 / 02 / 16$ & OOS & 623,600 \\
\hline $06 / 03 / 16$ & OOS & 488,210 \\
\hline
\end{tabular}

\begin{tabular}{|c|c|c|}
\hline Date & $\begin{array}{c}\text { North Pond } \\
\text { (gal) }\end{array}$ & $\begin{array}{c}\text { South Pond } \\
\text { (gal) }\end{array}$ \\
\hline $06 / 04 / 16$ & OOS & 587,390 \\
\hline $06 / 05 / 16$ & OOS & 572,110 \\
\hline $06 / 06 / 16$ & OOS & 519,530 \\
\hline $06 / 07 / 16$ & OOS & 558,820 \\
\hline $06 / 08 / 16$ & OOS & 636,080 \\
\hline $06 / 09 / 16$ & OOS & 475,680 \\
\hline $06 / 10 / 16$ & OOS & 556,110 \\
\hline $06 / 11 / 16$ & OOS & 557,060 \\
\hline $06 / 12 / 16$ & OOS & 552,720 \\
\hline $06 / 13 / 16$ & OOS & 553,380 \\
\hline $06 / 14 / 16$ & OOS & 562,940 \\
\hline $06 / 15 / 16$ & OOS & 584,680 \\
\hline $06 / 16 / 16$ & OOS & 583,000 \\
\hline $06 / 17 / 16$ & OOS & 604,490 \\
\hline $06 / 18 / 16$ & OOS & 596,010 \\
\hline $06 / 19 / 16$ & OOS & 569,500 \\
\hline $06 / 20 / 16$ & OOS & 675,580 \\
\hline $06 / 21 / 16$ & OOS & 654,920 \\
\hline $06 / 22 / 16$ & OOS & 635,000 \\
\hline $06 / 23 / 16$ & OOS & 597,100 \\
\hline $06 / 24 / 16$ & OOS & 546,910 \\
\hline $06 / 25 / 16$ & OOS & 608,280 \\
\hline $06 / 26 / 16$ & OOS & 420,270 \\
\hline $06 / 27 / 16$ & OOS & 199,440 \\
\hline $06 / 28 / 16$ & OOS & 466,430 \\
\hline $06 / 29 / 16$ & OOS & 749,420 \\
\hline $06 / 30 / 16$ & OOS & 562,880 \\
\hline $07 / 01 / 16$ & 542,680 & OOS \\
\hline $07 / 02 / 16$ & 660,350 & OOS \\
\hline $07 / 03 / 16$ & 732,240 & OOS \\
\hline $07 / 04 / 16$ & 435,000 & OOS \\
\hline $07 / 05 / 16$ & 616,250 & OOS \\
\hline $07 / 06 / 16$ & 647,440 & OOS \\
\hline $07 / 07 / 16$ & 631,070 & OOS \\
\hline $07 / 08 / 16$ & 592,500 & OOS \\
\hline $07 / 09 / 16$ & 624,800 & OOS \\
\hline $07 / 10 / 16$ & 578,230 & OOS \\
\hline $07 / 11 / 16$ & 724,420 & OOS \\
\hline $07 / 12 / 16$ & 480,590 & OOS \\
\hline $07 / 13 / 16$ & 701,730 & OOS \\
\hline $07 / 14 / 16$ & 446,000 & OOS \\
\hline $07 / 15 / 16$ & 575,070 & OOS \\
\hline $07 / 16 / 16$ & 613,140 & OOS \\
\hline $07 / 17 / 16$ & 638,580 & OOS \\
\hline $07 / 18 / 16$ & 600,160 & OOS \\
\hline $07 / 19 / 16$ & 567,500 & OOS \\
\hline
\end{tabular}




\begin{tabular}{|c|c|c|}
\hline Date & $\begin{array}{l}\text { North Pond } \\
\text { (gal) }\end{array}$ & $\begin{array}{l}\text { South Pond } \\
\text { (gal) }\end{array}$ \\
\hline $07 / 20 / 16$ & 602,830 & OOS \\
\hline $07 / 21 / 16$ & 603,080 & OOS \\
\hline $07 / 22 / 16$ & 428,340 & OOS \\
\hline $07 / 23 / 16$ & 561,120 & OOS \\
\hline $07 / 24 / 16$ & 683,860 & OOS \\
\hline $07 / 25 / 16$ & 555,270 & OOS \\
\hline $07 / 26 / 16$ & 666,520 & OOS \\
\hline $07 / 27 / 16$ & 606,930 & OOS \\
\hline $07 / 28 / 16$ & 617,140 & OOS \\
\hline $07 / 29 / 16$ & 627,500 & OOS \\
\hline $07 / 30 / 16$ & 635,200 & OOS \\
\hline $07 / 31 / 16$ & 570,630 & OOS \\
\hline $08 / 01 / 16$ & OOS & 654,580 \\
\hline $08 / 02 / 16$ & OOS & 626,060 \\
\hline $08 / 03 / 16$ & OOS & 595,660 \\
\hline $08 / 04 / 16$ & OOS & 671,090 \\
\hline $08 / 05 / 16$ & OOS & 624,750 \\
\hline $08 / 06 / 16$ & OOS & 495,250 \\
\hline $08 / 07 / 16$ & OOS & 712,710 \\
\hline $08 / 08 / 16$ & OOS & 595,120 \\
\hline $08 / 09 / 16$ & OOS & 693,020 \\
\hline $08 / 10 / 16$ & OOS & 595,340 \\
\hline $08 / 11 / 16$ & OOS & 598,220 \\
\hline $08 / 12 / 16$ & OOS & 676,200 \\
\hline $08 / 13 / 16$ & OOS & 603,010 \\
\hline $08 / 14 / 16$ & OOS & 642,420 \\
\hline $08 / 15 / 16$ & OOS & 614,350 \\
\hline $08 / 16 / 16$ & OOS & 555,310 \\
\hline $08 / 17 / 16$ & OOS & 666,000 \\
\hline $08 / 18 / 16$ & OOS & 607,490 \\
\hline $08 / 19 / 16$ & OOS & 658,580 \\
\hline $08 / 20 / 16$ & OOS & 564,290 \\
\hline $08 / 21 / 16$ & OOS & 648,180 \\
\hline $08 / 22 / 16$ & OOS & 625,970 \\
\hline $08 / 23 / 16$ & OOS & 660,130 \\
\hline $08 / 24 / 16$ & OOS & 525,310 \\
\hline $08 / 25 / 16$ & OOS & 681,270 \\
\hline $08 / 26 / 16$ & OOS & 680,900 \\
\hline $08 / 27 / 16$ & OOS & 522,310 \\
\hline $08 / 28 / 16$ & OOS & 567,480 \\
\hline $08 / 29 / 16$ & OOS & 629,100 \\
\hline $08 / 30 / 16$ & OOS & 676,540 \\
\hline $08 / 31 / 16$ & OOS & 607,060 \\
\hline $09 / 01 / 16$ & OOS & 625,760 \\
\hline $09 / 02 / 16$ & OOS & 640,420 \\
\hline $09 / 03 / 16$ & OOS & 618,210 \\
\hline
\end{tabular}

\begin{tabular}{|c|c|c|}
\hline Date & $\begin{array}{c}\text { North Pond } \\
\text { (gal) }\end{array}$ & $\begin{array}{c}\text { South Pond } \\
\text { (gal) }\end{array}$ \\
\hline $09 / 04 / 16$ & OOS & 626,900 \\
\hline $09 / 05 / 16$ & 605,070 & OOS \\
\hline $09 / 06 / 16$ & 575,400 & OOS \\
\hline $09 / 07 / 16$ & 601,540 & OOS \\
\hline $09 / 08 / 16$ & 757,850 & OOS \\
\hline $09 / 09 / 16$ & 471,870 & OOS \\
\hline $09 / 10 / 16$ & 636,550 & OOS \\
\hline $09 / 11 / 16$ & 633,710 & OOS \\
\hline $09 / 12 / 16$ & 626,590 & OOS \\
\hline $09 / 13 / 16$ & 524,530 & OOS \\
\hline $09 / 14 / 16$ & 639,030 & OOS \\
\hline $09 / 15 / 16$ & 727,490 & OOS \\
\hline $09 / 16 / 16$ & 369,660 & OOS \\
\hline $09 / 17 / 16$ & 146,300 & OOS \\
\hline $09 / 18 / 16$ & 178,520 & OOS \\
\hline $09 / 19 / 16$ & 242,300 & OOS \\
\hline $09 / 20 / 16$ & 405,940 & OOS \\
\hline $09 / 21 / 16$ & 403,260 & OOS \\
\hline $09 / 22 / 16$ & 418,370 & OOS \\
\hline $09 / 23 / 16$ & 366,630 & OOS \\
\hline $09 / 24 / 16$ & 367,000 & OOS \\
\hline $09 / 25 / 16$ & 390,650 & OOS \\
\hline $09 / 26 / 16$ & 383,100 & OOS \\
\hline $09 / 27 / 16$ & 389,580 & OOS \\
\hline $09 / 28 / 16$ & 365,270 & OOS \\
\hline $09 / 29 / 16$ & 400,190 & OOS \\
\hline $09 / 30 / 16$ & 387,150 & OOS \\
\hline $10 / 01 / 16$ & 396,150 & OOS \\
\hline $10 / 02 / 16$ & 349,790 & OOS \\
\hline $10 / 03 / 16$ & OOS & 348,740 \\
\hline $10 / 04 / 16$ & OOS & 414,540 \\
\hline $10 / 05 / 16$ & OOS & 395,240 \\
\hline $10 / 06 / 16$ & OOS & 424,480 \\
\hline $10 / 07 / 16$ & OOS & 383,770 \\
\hline $10 / 08 / 16$ & OOS & 371,990 \\
\hline $10 / 09 / 16$ & OOS & 371,860 \\
\hline $10 / 10 / 15$ & OOS & 377,890 \\
\hline $10 / 11 / 16$ & OOS & 379,820 \\
\hline $10 / 12 / 16$ & OOS & 384,490 \\
\hline $10 / 13 / 16$ & OOS & 424,480 \\
\hline $10 / 14 / 16$ & OOS & 369,280 \\
\hline $10 / 15 / 16$ & OOS & 405,810 \\
\hline $10 / 16 / 16$ & OOS & 393,230 \\
\hline $10 / 17 / 16$ & OOS & 397,880 \\
\hline $10 / 18 / 16$ & OOS & 380,140 \\
\hline $10 / 19 / 16$ & OOS & 416,600 \\
\hline & & \\
\hline & & \\
\hline 000
\end{tabular}




\begin{tabular}{|c|c|c|}
\hline Date & $\begin{array}{c}\text { North Pond } \\
\text { (gal) }\end{array}$ & $\begin{array}{c}\text { South Pond } \\
\text { (gal) }\end{array}$ \\
\hline $10 / 20 / 16$ & OOS & 487,420 \\
\hline $10 / 21 / 16$ & OOS & 250,920 \\
\hline $10 / 22 / 16$ & OOS & 446,290 \\
\hline $10 / 23 / 16$ & OOS & 333,650 \\
\hline $10 / 24 / 16$ & OOS & 418,250 \\
\hline $10 / 25 / 16$ & OOS & 325,350 \\
\hline $10 / 26 / 16$ & OOS & 322,970 \\
\hline
\end{tabular}

\begin{tabular}{|c|c|c|}
\hline Date & $\begin{array}{c}\text { North Pond } \\
\text { (gal) }\end{array}$ & $\begin{array}{c}\text { South Pond } \\
\text { (gal) }\end{array}$ \\
\hline $10 / 27 / 16$ & OOS & 241,780 \\
\hline $10 / 28 / 16$ & OOS & 264,490 \\
\hline $10 / 29 / 16$ & OOS & 298,560 \\
\hline $10 / 30 / 16$ & OOS & 281,500 \\
\hline $10 / 31 / 16$ & OOS & 297,680 \\
\hline $\begin{array}{l}\text { a. OOS indicates pond was out of service. The } \\
\text { respective pond is operable, but not receiving effluent. }\end{array}$ \\
\hline
\end{tabular}

